\title{
CEsifo WORKING

\section{Early Effects of the COVID-19 Pandemic on Housing Market in the United States}

BarışK. Yörük 


\section{Impressum:}

CESifo Working Papers

ISSN 2364-1428 (electronic version)

Publisher and distributor: Munich Society for the Promotion of Economic Research - CESifo

$\mathrm{GmbH}$

The international platform of Ludwigs-Maximilians University's Center for Economic Studies and the ifo Institute

Poschingerstr. 5, 81679 Munich, Germany

Telephone +49 (0)89 2180-2740, Telefax+49 (0)89 2180-17845, email office@cesifo.de

Editor: Clemens Fuest

https://www.cesifo.org/en/wp

An electronic version of the paper may be downloaded

- from the SSRN website: www.SSRN.com

- from the RePEc website: $\quad$ www.RePEc.org

- from the CESifo website: https://www.cesifo.org/en/wp 


\title{
Early Effects of the COVID-19 Pandemic on Housing Market in the United States
}

\begin{abstract}
I use daily data from fifty major cities to investigate the early effects of the COVID-19 pandemic on housing market in the United States. I find that starting from the second half of March, 2020, new home listings and pending home sales started to decrease. By mid-April, certain markets experienced more than $60 \%$ drop in new home listings and pending home sales relative to the same time period in the previous year. The collapse of the housing market is broad based, hitting all major cities, regardless of the intensity of virus spread or timing of the introduction of state level policies to combat the pandemic. The only exception is the closure of non-essential businesses at certain states, which is associated with up to a 9 percentage point decrease in new home listings.
\end{abstract}

JEL-Codes: I180, R310.

Keywords: covid-19, housing market, United States.

\author{
Barış K. Yörük \\ Department of Economics \\ University at Albany, SUNY \\ 1400 Washington Ave. \\ USA - Albany, NY 12222 \\ byoruk@albany.edu
}

May 25, 2020 


\section{Introduction}

The Novel Coronavirus (COVID-19) is an infectious disease that spread to more than 200 countries by May, 2020. The World Health Organization (WHO) on March 11, 2020, has declared the COVID-19 outbreak a global pandemic. The early cases of COVID-19 was confirmed in the United States by January, 2020. As of May 2020, more than 4.5 million confirmed cases of COVID-19 and more than 300,000 COVID-19 related deaths were reported globally. Approximately, 30\% of all confirmed cases and deaths related to COVID-19 were reported in the United States. Several recent studies document the negative impact of the coronavirus pandemic on U.S. economy (Baker, Bloom, Davis, and Terry, 2020; Atkeson, 2020; Lewis, Mertens, and Stock, 2020). The existing literature also documents that pandemics have considerable negative effects on housing markets and some negative effects may be persistent even in the very long-run (Ambrus, Field,and Gonzales, 2020). This paper contributes to this literature by providing the first estimates of the early effects of the COVID-19 pandemic on housing market in the United States.

During the pandemic, majority of U.S. states implemented several different policies to slow the spread of the COVID-19. Examples of these policies include shutting down certain businesses that are deemed non-essential, closing schools, ordering people to stay at home, and imposing restrictions on large gatherings. Recent papers show that these policies were effective in slowing down the spread of the virus among the population (Martin-Calvo, et al., 2020) and reduced the movement and social interactions of individuals (Dave et al., 2020; Friedson et al., 2020; Gupta et al., 2020). However, these policies also require reductions in economic activity and may have long-lasting impacts on economy. For instance, recent studies show that these policies had a significant impact on unemployment insurance claims during the pandemic (Kong and Prinz, 2020). This paper also contributes to this literature by investigating the effects of the state level policies to mitigate the spread of the COVID-19 on housing market activity in the United States.

I use daily housing data from 50 major U.S. cities from February 15 to April 19, 2020. During this time period, total COVID-19 cases in the United States has reached to more than 750, 000 from just 15. Using event study and difference-in-differences (DD) type models, I document that the collapse of the housing market in the United States is broad based, hitting all major cities during the same time period. The intensity of virus spread at the county level had a very little effect on the collapse of the housing market. Under certain specifications, I find that a $10 \%$ increase in the alternative indicators 
of COVID-19 related cases or deaths is associated with a 0.1 to 0.03 percentage point decrease in housing market activity, relative to the same time period in the previous year. I also find that the majority of the policies that were introduced to combat the pandemic had no significant impact on the housing market. The only exception is the closure of non-essential businesses. I find that this policy is associated with up to a 9 percentage point decrease in the number of newly listed homes relative to the same time period in the previous year.

\section{Background and existing literature}

The coronavirus epidemic hit the United States relatively late. The first case of COVID-19 in the United States was confirmed on January $20^{t h}$, 2020, when parts of China were already under a quarantine order. The first COVID-19 related death in the United States was reported on February, 29. Washington was the first state to issue a state of emergency on the same date, with New York and California following the next week. There were 100 cases by March 4, 2020, 10,000 cases by March 18, and more than one million cases by April 28. By mid May, more than 1.4 million cases and 85, 000 deaths have been reported in the United States (Center for Disease Control and Prevention, 2020).

From mid March to early April, 2020, many states adopted policies to mitigate the spread of the coronavirus. These include stay-at-home orders, non-essential business closures, bans on large gatherings, school closures, and closings of certain businesses such as restaurants and bars. By April 20, 2020, all states with the exceptions of Arkansas, Iowa, Nebraska, North Dakota, South Dakota, and Wyoming have issued some form of a stay-at-home order. By the same time, all states with the exceptions of Arkansas, Minnesota, Nebraska, South Dakota, Texas, Utah, and Wyoming had implemented some form of non-essential business closures. Initial implementation of these policies across different states occurred at different times. Kong and Prinz (2020) show that although announcement dates of the policies across different states are positively correlated, the correlation is weak in most cases. Appendix Table A1 shows when these policies were first implemented for 50 cities used in the empirical analysis.

Several recent papers investigate the early effects of the coronavirus pandemic and state level policies to control the spread of the virus on economic and social outcomes in the United States. Engle, Stromme, and Zhou (2020) find that local infection rate and stay-at-home-orders are signifi- 
cantly associated with reduction in mobility. Painter and Qiu (2020) document that political beliefs present a significant limitation to the effectiveness of state-level social distancing orders to mitigate the spread of coronavirus. In particular, residents in Republican counties are less likely to completely stay at home after a state order has been implemented relative to those in Democratic counties. Allcott, et al. (2020) also show that Republicans engage in less social distancing, even after controlling for other factors including state policies, population density, and local COVID-19 cases and deaths. Beland, Brodeur, and Wright (2020) document that COVID-19 increased the unemployment rate and decreased hours of work and labor force participation in the United States, but had no significant impact on wages. Kahn, Lange, and Wiczer (2020) show that job vacancies in the United States significantly dropped in the second half of the March, 2020. This drop was broad based and independent of the intensity of the initial virus spread or timing of stay-at-home policies. The only major exceptions were in essential retail and nursing, the jobs that were most in-demand during the coronavirus crisis. Kong and Prinz (2020) find that restaurant and bar limitations and non-essential business closures could explain $4.4 \%$ and $8.5 \%$ of unemployment insurance (UI) claims in the United States respectively, while the other state level policies did not have an impact on UI claims. Baker, et al. (2020) find that U.S. households substantially changed their spending habits as news about the COVID-19's impact in their area spread. Overall, spending increased dramatically in an attempt to stockpile needed home goods and also in anticipation of the inability to patronize retailers.

To the best of my knowledge, this is the first paper that investigates the effects of the coronavirus pandemic on U.S. housing market. ${ }^{1}$ There is also a broader literature, which investigates the effects of health shocks and pandemics on housing market. Ambrus, Field, and Gonzales (2020) examine the impact on housing prices of a cholera epidemic in one neighborhood of nineteenth century London. They show that ten years after the epidemic, housing prices are significantly lower just inside the catchment area of the water pump that transmitted the disease. Moreover, differences in housing prices persist over the following 160 years. Francke and Korevaar (2020) investigate the effects of historical outbreaks of the plague in $17^{\text {th }}$ century Amsterdam and cholera in $19^{\text {th }}$ century Paris

\footnotetext{
${ }^{1}$ European Economic Association hosts a registry of research projects related to impacts of coronavirus pandemic on economic and social outcomes. As of May 15, 2020, the only project in this regitry related to the effects of COVID-19 on U.S. housing market is entitled "The effect of COVID-19 on home prices and sales" by Elliot Anenberg. He proposes to analyze the effect of COVID-19 on home prices and sales in the United States by using a dataset on approved purchase mortgage applications. To the best of my knowledge, this project is still ongoing and a working paper is not available. Furthermore, this paper uses a different data set to investigate the effect of coronavirus pandemic on the U.S. housing market.
} 
on housing prices. They find that outbreaks resulted in large declines in house prices, and smaller declines in rent prices, with large reductions in house prices during the first six months of an epidemic in heavily-affected areas. They also show that price shocks were transitory, and both cities quickly reverted to their initial price paths. Wong (2008) finds that SARS epidemic led to a $1.6 \%$ fall in home values and $72 \%$ fall in transactions volume in Hong Kong. Davis (2004) investigates the effect of a health risk, a cluster of cases of pediatric leukemia in an isolated county of Nevada, on housing prices. He finds that compared with unaffected counties, housing prices in the affected county declined significantly during the period of maximum risk. In a recent paper, Currie, et al. (2015) investigate the effect of toxic emissions from industrial plants on housing values and find that industrial plant openings lead to 11 percent declines in housing values within 0.5 mile. This paper contributes to this literature by investigating the effects COVID-19 pandemic and state level policies to mitigate the spread of virus on housing market in the United States.

\section{Data and methodology}

I use data on daily confirmed coronavirus cases and deaths for each county from USAFacts (USAFacts, 2020). I use county population data from 2019 Census estimates to calculate per capita number of cases and deaths for each county. Most cities in my sample is a part of a single county. However, I use the cumulative population, number of cases, and deaths from multiple counties for few cities. ${ }^{2}$ Recent papers show that residents in Republican counties are less likely to comply with policies that were introduced to control the spread of the virus. I estimate models that exclude counties where share of the Republican votes were less than $50 \%$. Data for county level election results from the 2016 Presidential election come from MIT Election Data and Science Lab (MIT, 2018).

There are a few sources that track the social distancing policies at the state level. I use the data assembled by The Institute for Health Metrics and Evaluation (IHME) at the University of Washington. because it is comprehensive and provides precise information on timing of the social distancing order. In particular, I use information on the timing of the introduction of bans on mass gatherings, any business closures that only affected certain businesses such as restaurants and bars, school closings, closures of all non-essential businesses, and stay-at-home orders.

Daily housing data come from Zillow, an online real estate database company. Housing market

\footnotetext{
${ }^{2}$ For instance, in order to calculate per capita cases and deaths for New York City, I use cumulative population, cases, and deaths from New York, Queens, Kings, and Bronx counties.
} 
in the United States follow a seasonal pattern, which typically rises every spring. In a recent data release, Zillow reports daily percentage change in the number of newly listed homes in the United States and 50 major U.S. cities relative to the same time period in the previous year for 65 consecutive days, from February 15 to April 19, 2020. These cities are the unit of observation for the empirical analysis and reported in Table A1. For the same time period, Zillow also reports daily percentage change in the number of pending home sales in the United States and 40 major U.S. cities. ${ }^{3}$ I also use information on percentage change in web traffic to for-sale listings relative to the same period in the previous year calculated as a 7-day moving average. Web traffic data are available from March 1 to April 15, 2020. Appendix Figure A1 shows the the trends in these variables for the United States. On February 15, 2020, when there were only 15 reported cases of COVID-19 in the United States, new home listings and pending sales were up by almost $20 \%$ and $30 \%$, respectively relative to the same time period in 2019. By March 24, both indicators were below their 2019 levels. On April 19, newly listed homes and pending sales in the United States were more than 30\% below their 2019 levels. Web traffic to for-sale listings exhibits a U-shape pattern. It was down by almost $20 \%$ by March 22 . However, it exhibits an increasing trend from that date until the end of the sample period.

Early cases of the coronavirus were seen in Washington, California, and Illinois. Intensity of the spread of the virus and total confirmed cases and deaths also differ considerably across different cities. As of April 19, 2020, New York City was by far the hardest hit with more than 158 cases per 10000 people (roughly one third of all cases in the United States). On the other hand, several cities in my sample such as San Antonio, Raleigh, and Phoenix had less than 6 cases per 10000 people on the same date. Figures 1 and 2 plot trends in daily percentage change in the number of newly listed homes and pending sales relative to the same time period in 2019 for selected cities in the sample. The figures show that housing market collapsed by late March across all cities regardless of the region. There is very little evidence that housing market in cities that were hit more heavily by the epidemic or that imposed more comprehensive social distancing policies were differentially affected. Pending home sales, for instance, were below their 2019 levels in Miami on March 12 when there were only 2 confirmed cases of COVID-19 in Miami while on the same date pending home sales were up by almost 30\% in New York City where 90 cases were reported. In New York City, pending home sales

\footnotetext{
${ }^{3}$ Data for daily percentage change in the number of pending sales relative to the same time period in the previous year are not available for the following cities: Memphis, Milwaukee, Minneapolis, Oklahoma City, Orlando, Richmond, San Francisco, San Jose, Tampa, and Virginia Beach. The data used in this paper were released by Zilllow through two recent publicly available reports (Tucker, 2020a; Tucker 2020b).
} 
dropped below their 2019 levels on March 24 when there were almost 14, 000 cases in New York City.

In order to formally estimate the effect of the spread of the coronavirus and state level social distancing policies on the U.S. housing market, I use two empirical models. First, I estimate an event study model that exploits differential policy announcement dates across different states. The main specification for this model for the cities that adopted a particular policy is of the form:

$$
Y_{i s t}=\sum_{j=-7}^{7} \delta_{j} \times 1\{d a y=j\}+\gamma_{i}+\varsigma_{s}+\mu_{t}+\varepsilon_{i s t}
$$

where $Y_{i s t}$ is one of the indicators of housing market for city $i$, located at state $s$, for the calendar date $t$, day denotes the days relative to the date that a particular policy was announced $(d a y=0)$ and $\gamma_{i}, \varsigma_{s}$, and $\mu_{t}$ are city, state, and calendar date fixed effects respectively. Standard errors are clustered at the state level. This model essentially contains series of dummy variables that control for each day of the weeks just before and after the day that a particular policy was announced. I exclude the day prior to the announcement date $(d a y=-1)$ so coefficients of interest $\delta_{j}$ estimate the differential change in outcome variables for each day $j$ relative to the day prior to the announcement date. Following Kong and Prinz (2020), for periods $j>7$ and $j<-7$, I assign $j=7$ and $j=-7$ respectively with the underlying assumption that the dynamic effects of the policy are constant 7 days before or after the policy announcement. ${ }^{4}$

Next, I use a DD type model to estimate the impact of state policies on different indicators of housing market. The main specification for this model is:

$$
Y_{i s t}=\beta^{\prime} \text { Policy }_{s t}+\alpha X_{i s t}+\gamma_{i}+\varsigma_{s}+\mu_{t}+v_{i s t}
$$

where, Policy $y_{\text {ist }}$ is a set of binary variables for policies adopted by state $s$ at calendar date $t$. These binary variables take the value of unity for the calendar dates for which $d a y \geq 0$. In several models, I control for the spread of the coronavirus at the county level $\left(X_{i s t}\right)$, either as total number of cases or deaths per 10,000 people or daily number of new cases or deaths per 10,000. I present the summary statistics for these variables in Appendix Table A2. Since daily new cases may follow a trend based on the calendar date due to increased testing or possible under or over reporting on

\footnotetext{
${ }^{4}$ Conducting an event study with an extended time period would rely on comparisons between states that adopted the policy early and states that adopted the policy at least one week later. However, in many occasions, state level policies to mitigate the spread of coronavirus were introducted at the same time or within few days apart across different states. Therefore, separately identifying calendar date fixed effects for an extended time period would rely on increasingly selected set of treated and control states.
} 
certain days (weekends vs. Mondays and Tuesdays), I also estimate models in which I interact daily new cases with calendar dates. Standard errors are clustered at the state level. The key identification assumption behind equation (2) is that alternative indicators of housing market follow a common trend for treatment and control cities (cities that adopted a particular policy at a given date vs. those did not) in the absence of the policies to control for the spread of coronavirus. Common trend assumption may fail when a policy endogeneity problem exists. However, it is not plausible that states that are experiencing relatively strong or weak housing markets are more or less likely to adopt these policies. Event study model in equation (1) also provides a pre-trend analysis of each policy since it includes terms that control for 2 to 7 days before the true adoption dates. In these models, dummy variables that capture the time periods before the policy change should not be significant. ${ }^{5}$

\section{Results}

Figure 3 and Appendix Tables A3 to A7 report the results for the event study models of the effect of state policies on daily percentage change in the number of newly listed homes and pending home sales under alternative specifications. Tables A3 and A4 show that restrictions of mass gatherings and school closures did not have a significant impact on the housing market. On the other hand, Figure 3 and the first specification in Table A5 show that the effects of closure of non-essential businesses on the housing market are negative and highly significant. In particular, this policy led to a 4 percentage point decrease in the number of new listings and 3 percentage point decrease in pending home sales relative to the same time period in the previous year, one day after the adoption date. The effects extend to long-run. One week after the adoption of this policy, number of new listings and pending home sales were down by 21 and 24 percentage points, respectively. For this policy, dummy variables that capture the time periods before the adoption date are insignificant as expected. I estimate several alternative models to test robustness of these results. Results reported in specifications 2 to 5 in Appendix Table A5 show that inclusion of daily new cases and deaths per capita to models, exclusion of New York (the most affected state from the pandemic) from the sample, exclusion of the states where the first cases were seen (California and Washington) from the sample, and exclusion of

\footnotetext{
${ }^{5}$ The timing and strength of policy implementation may be endogenous to the expectations regarding the effectiveness of other social distancing strategies. Although, calendar day fixed effects adjust for timing issues and controls for the number of total and daily cases and deaths in certain models account for how seriously a city would take the pandemic, I cannot completely rule out this possibility.
} 
cities where Republican votes were higher than $50 \%$ in the 2016 Presidential election from the sample (exclusion of Kansas and Oklahoma) does not have a meaningful impact on the benchmark results reported in the first specification of the table and panel D of Figure $3 .^{6}$ Panel E of Figure 3 and first three specification of Table A7 provide some evidence that stay-at-home orders had a significant negative impact on the number of newly listed homes 5 to 7 days after the policy adoption date. However, significant effects disappear when New York, California, and Washington are excluded from the sample. In Appendix Table A8, I also provide event study estimates for the effect of state level policies on the change in web page views of for-sale homes. The closure of non-essential businesses appear to be the only policy that had a significant negative impact on the web traffic to for-sale homes. However, these estimates should be interpreted with caution since the estimates for pre-periods (up to 4 days before the policy announcement date) are also statistically significant.

Table 1 reports the DD estimates of the effect of the spread of the coronavirus and state level social distancing policies on the percentage change in the number of newly listed homes relative to the same time period in the previous year. The benchmark model reported in the first specification shows that closure of non-essential businesses is associated with a 9 percentage point decrease in the number of newly listed homes. The estimated impact of the remaining policies are relatively small and statistically insignificant. Specifications 2 to 6 add alternative indicators of the spread of the coronavirus at the county level. The remaining specifications drop certain states from the sample. The negative impact of the closure of the non-essential businesses on new listings is robust under these specifications. In specifications 3 to 6 , the coefficients on alternative control variables are relatively small and marginally significant. For instance, in specification 3, a one point increase in the total number of cases per 10,000 people at the county level (18.4\% increase from the mean of this variable) decreases the number of newly listed homes by 0.2 percentage points. However, this effect is not robust to the exclusion of New York from the sample. ${ }^{7}$ Similarly, a $10 \%$ percent increase in daily new deaths at the county level relative to the mean of this variable (0.019) corresponds to a 0.03

\footnotetext{
${ }^{6}$ There are only two cities in my sample in which Republican votes in the 2016 Presidential election were higher than 50\%. These cities are Kansas City and Oklahoma City. In my sample, these are the only cities that represent their states. Therefore, dropping these two cities from the sample is equivalent of dropping Kansas and Oklahoma from the sample. Since I do not have data on change in pending home sales for these cities, I cannot estimate models that exclude these two cities from the sample for this particular outcome.

${ }^{7}$ Although not reported, I also estimate DD type models in which I control for total or daily cases and deaths per 10,000 people jointly. In majority of these models, coefficients of both vaiables were statistically insignificant. These results are available upon request.
} 
$(0.173 \times 0.0019)$ percentage point decrease in the number of newly listed homes relative to the same period in the previous year.

Event study estimates show a negative impact of non-essential business closures on pending sales for cities that are located in states that adopted this policy. However this effect disappears in DD type models that control for other social distancing policies and include cities that did not impose any restrictions on non-essential businesses. Table 2 shows that none of the state level policies to mitigate the spread of coronavirus had a significant impact on pending home sales. In specifications 3 to 6 , the effect of the variables that control for the spread of the virus at the county level is significant but relatively small. As in Table 1, this effect also disappears when New York, or Washington and California are excluded from the sample.

Table 3 reports DD estimates of the effect of state level policies on web page views of for-sale homes. The results show that closure of non-essential businesses is associated with a 5.5 to 7.2 percentage point decrease in web traffic to for-sale-homes. However, these results should be interpreted with caution since event study estimates show statistically significant effects of this policy on web page views even before the policy adoption date. Furthermore, the results reported in specification 8 of Table 3 show that the significant effect of this policy is sensitive to the sample selection. The effects of other social distancing policies on web traffic to for-sale homes are relatively small and not significant. Similarly, number of COVID-19 related cases or deaths at the county level has a negative but a minor impact on web page views of for-sale homes.

\section{Conclusion}

As of May, 2020, United States is the hardest hit country from the coronavirus pandemic with more than 1.4 million cases and 85,000 deaths. From mid March to early April, 2020, many U.S. states adopted policies to mitigate the spread of the coronavirus. Using daily data from 50 major U.S. cities from February 15 to April 19, 2020, this paper provides the first estimates of the early effects of the COVID-19 and state level policies to control the pandemic on housing market in the United States. Inspection of raw data and estimates from the event study and DD type models suggest that the collapse of the housing market in the United States is broad based, hitting all major cities, regardless of the intensity of virus spread or timing of the introduction of state level policies to combat the pandemic. Although there is some evidence that alternative indicators of COVID-19 related cases 
and deaths at the county level have a significant impact on the decline of the number of newly listed homes, pending sales, and web traffic to for-sale homes over time, the effect of these variables are relatively small. For certain specifications, I find that a $10 \%$ increase in the alternative indicators of COVID-19 related cases or deaths is associated with a 0.1 to 0.03 percentage point decrease in housing market activity.

Among others, the closure of non-essential businesses at certain states appear to be the only policy which had a significant and considerable impact on the housing market. I find that introduction of this policy is associated with up to a 9 percentage point decrease in the number of newly listed homes relative to the same period in the previous year. This result is not surprising since majority of homes in the United States are sold by real estate agents who were considered as non-essential workers in many states that adopted the closure of non-essential businesses policy. Some states such as New York later relaxed their policy and allowed real estate agents to conduct their business. In reality however, real estate agents were not allowed to meet with their clients in person and were only allowed to show properties virtually, especially if the state has a stay-at-home order in place. An increasing trend in web traffic to for-sale listings after the majority of state level policies were adopted by late March,2020 may also be explained by this policy and stay-at-home orders.

This paper provides an early analysis of the impact of the COVID-19 pandemic on U.S. housing market. The raw data show an increasing trend in home listings and pending sales after April 16, 2020. Although this may be seen as an early sign of recovery, it is not clear whether this increasing trend will continue in the long-run and the pandemic will have a significant impact on housing prices. Future research will investigate these questions when U.S. housing market data for the post-pandemic period become available.

\section{References}

[1] Allcott, et al., 2020, Polarization and Public Health: Partisan Differences in Social Distancing during the Coronavirus Pandemic, NBER Working Paper No. 26946.

[2] Ambrus, A., E. Field, R. Gonzalez, 2020, Loss in the time of cholera: Long-run impact of a disease epidemic on the urban landscape, American Economic Review, 110, 475-525.

[3] Atkeson, A., 2020, What will be the economic impact of COVID-19 in the US? Rough estimates of disease scenarios, NBER Working Paper No. 26867. 
[4] Baker, S., et al., 2020, How does household spending respond to an epidemic? Consumption during the 2020 COVID-19 Pandemic, NBER Working Paper No. 26949.

[5] Baker, S., N. Bloom, S.J. Davis, and S.J. Terry, 2020, COVID-Induced economic uncertainty, NBER Working Paper No. 26983.

[6] Beland, L., A. Brodeur, and T. Wright, 2020, The short-term economic consequences of COVID19: Exposure to disease, remote work and government response, IZA Discussion Paper No. 13159.

[7] Centers for Disease Control and Prevention, 2020, Cases of Coronavirus Disease (COVID-19) in the U.S. Available at: https: //www. cdc. gov/coronavirus/ 2019-ncov/cases-updates/cases-inus.html.

[8] Dave, D., et al, 2020, When do shelter-in-place orders fight COVID-19 best? Policy heterogeneity across states and adoption time, NBER Working Paper No. 27091.

[9] Curie, et al., 2015, Environmental health risks and housing values: Evidence from 1,600 toxic plant openings and closings, American Economic Review, 105, 678-709.

[10] Davis, L.W., 2004, The effect of health risk on housing values: Evidence from a cancer cluster, American Economic Review, 94, 1693-1704.

[11] Engle, S., J. Stromme, and A. Zhou, 2020, Staying at home: Mobility effects of COVID-19, Unpublished Manuscript.

[12] Friedson, A.I., et al., 2020, Did California's shelter-in-place order work? Early coronavirusrelated public health effects, NBER Working Paper 26992.

[13] Francke, M. and M. Korevaar, 2020, Housing markets in a pandemic: Evidence from historical outbreaks, Unpublished Manuscript. Available at: http://dx.doi.org/10.2139/ssrn.3566909.

[14] Gupta, S., et al, 2020, Tracking public and private responses to the COVID-19 epidemic: Evidence from state and local government actions, NBER Working Paper No. 27027.

[15] Kahn, L., F. Lange, and D.G. Wiczer, 2020, Labor demand in the time of covid-19: Evidence from vacancy postings and UI claims, NBER Working Paper No. 27061. 
[16] Lewis, D., K. Mertens, and J.H. Stock, 2020, U.S. economic activity during the early weeks of the SARS-Cov-2 outbreak, NBER Working Paper No. 26954.

[17] Kong, E. and D. Prinz, 2020, The impact of shutdown policies on unemployment during a pandemic, Unpublished Manuscript.

[18] Martin-Calvo, D., et al., 2020, Effectiveness of social distancing strategies for protecting a community from a pandemic with a data-driven contact network based on census and real-world mobility data, DSS MIT / University of Zaragoza / UC3M / ISI Foundation. https://covid-19sds.github.io/assets/pdfs/Preliminary_Report_Effectiveness_of_social_distance_strategies_COVID19.pdf.

[19] MIT, 2018, County Presidential Election Returns 2000-2016. doi:10.7910/DVN/VOQCHQ

[20] Painter, M.O. and T.Qiu, 2020, Political beliefs affect compliance with COVID-19 social distancing orders, Unpublished Manuscript.

[21] Tucker, J., 2020a, Web visits to for-sale listings rebounding as spring unfolds, https://www.zillow.com/research/page-views-for-sale-listings-2020-26829/.

[22] Tucker, J., 2020b, Early data point to slight housing turnaround after initial coronavirus pullback (March 2020 Market Report), https://www.zillow.com/research/listings-by-price-tiercoronavirus-26965/

[23] USAFacts, 2020, available at: https://usafacts.org/visualizations/coronavirus-covid-19-spreadmap/

[24] Wong, G., 2008, Has SARS infected the property market? Evidence from Hong Kong, Journal of Urban Economics, 63, 74-95. 
Table 1. The effect of state level policies on newly listed homes

\begin{tabular}{|c|c|c|c|c|c|c|c|c|c|}
\hline & $(1)$ & $(2)$ & (3) & (4) & (5) & (6) & $(7)$ & (8) & (9) \\
\hline Ban on mass gatherings & $\begin{array}{c}0.013 \\
(0.023)\end{array}$ & $\begin{array}{c}0.014 \\
(0.024)\end{array}$ & $\begin{array}{c}0.011 \\
(0.022)\end{array}$ & $\begin{array}{c}0.010 \\
(0.022)\end{array}$ & $\begin{array}{c}0.012 \\
(0.022)\end{array}$ & $\begin{array}{c}0.011 \\
(0.022)\end{array}$ & $\begin{array}{c}0.009 \\
(0.022)\end{array}$ & $\begin{array}{c}0.031 \\
(0.023)\end{array}$ & $\begin{array}{c}0.011 \\
(0.023)\end{array}$ \\
\hline School closures & $\begin{array}{l}-0.011 \\
(0.032)\end{array}$ & $\begin{array}{l}-0.010 \\
(0.031)\end{array}$ & $\begin{array}{l}-0.012 \\
(0.031)\end{array}$ & $\begin{array}{l}-0.011 \\
(0.031)\end{array}$ & $\begin{array}{l}-0.012 \\
(0.031)\end{array}$ & $\begin{array}{l}-0.011 \\
(0.031)\end{array}$ & $\begin{array}{l}-0.010 \\
(0.032)\end{array}$ & $\begin{array}{l}-0.023 \\
(0.031)\end{array}$ & $\begin{array}{c}0.001 \\
(0.031)\end{array}$ \\
\hline Closure of any business & $\begin{array}{l}-0.026 \\
(0.054)\end{array}$ & $\begin{array}{l}-0.028 \\
(0.053)\end{array}$ & $\begin{array}{l}-0.028 \\
(0.052)\end{array}$ & $\begin{array}{l}-0.028 \\
(0.053)\end{array}$ & $\begin{array}{l}-0.027 \\
(0.052)\end{array}$ & $\begin{array}{l}-0.028 \\
(0.053)\end{array}$ & $\begin{array}{l}-0.029 \\
(0.053)\end{array}$ & $\begin{array}{l}-0.041 \\
(0.057)\end{array}$ & $\begin{array}{l}-0.055 \\
(0.049)\end{array}$ \\
\hline Closure of non-essential business & $\begin{array}{c}-0.090^{* *} \\
(0.035)\end{array}$ & $\begin{array}{c}-0.076^{* *} \\
(0.032)\end{array}$ & $\begin{array}{c}-0.076^{* *} \\
(0.033)\end{array}$ & $\begin{array}{c}-0.081 * * \\
(0.035)\end{array}$ & $\begin{array}{c}-0.079 * * \\
(0.032)\end{array}$ & $\begin{array}{c}-0.083^{* *} \\
(0.035)\end{array}$ & $\begin{array}{c}-0.068^{* *} \\
(0.033)\end{array}$ & $\begin{array}{c}-0.071 * \\
(0.039)\end{array}$ & $\begin{array}{c}-0.080 * * \\
(0.035)\end{array}$ \\
\hline Stay at home order & $\begin{array}{c}0.012 \\
(0.034)\end{array}$ & $\begin{array}{c}0.008 \\
(0.031)\end{array}$ & $\begin{array}{c}0.006 \\
(0.031)\end{array}$ & $\begin{array}{c}0.008 \\
(0.033)\end{array}$ & $\begin{array}{c}0.009 \\
(0.030)\end{array}$ & $\begin{array}{c}0.009 \\
(0.032)\end{array}$ & $\begin{array}{c}0.014 \\
(0.032)\end{array}$ & $\begin{array}{c}0.016 \\
(0.037)\end{array}$ & $\begin{array}{c}0.008 \\
(0.034)\end{array}$ \\
\hline Total cases per 10000 & & & $\begin{array}{c}-0.002 * \\
(0.001)\end{array}$ & & & & $\begin{array}{l}-0.002 \\
(0.001)\end{array}$ & $\begin{array}{l}-0.002 \\
(0.001)\end{array}$ & $\begin{array}{c}-0.002 * \\
(0.001)\end{array}$ \\
\hline Total deaths per 10000 & & & & $\begin{array}{c}-0.020 * \\
(0.010)\end{array}$ & & & & & \\
\hline New cases per 10000 & & & & & $\begin{array}{c}-0.024^{*} \\
(0.013)\end{array}$ & & & & \\
\hline New deaths per 10000 & & & & & & $\begin{array}{c}-0.173^{*} \\
(0.087) \\
\end{array}$ & & & \\
\hline $\mathrm{N}$ & 3250 & 3250 & 3250 & 3250 & 3250 & 3250 & 3120 & 2665 & 3185 \\
\hline Daily case count $\times$ calendar date & $\mathrm{N}$ & $\mathrm{Y}$ & $\mathrm{N}$ & $\mathrm{N}$ & $\mathrm{N}$ & $\mathrm{N}$ & $\mathrm{N}$ & $\mathrm{N}$ & $\mathrm{N}$ \\
\hline Drop NY & $\mathrm{N}$ & $\mathrm{N}$ & $\mathrm{N}$ & $\mathrm{N}$ & $\mathrm{N}$ & $\mathrm{N}$ & $\mathrm{Y}$ & $\mathrm{Y}$ & $\mathrm{N}$ \\
\hline Drop NY, WA, and CA & $\mathrm{N}$ & $\mathrm{N}$ & $\mathrm{N}$ & $\mathrm{N}$ & $\mathrm{N}$ & $\mathrm{N}$ & $\mathrm{N}$ & Y & $\mathrm{N}$ \\
\hline Drop KS and OK & $\mathrm{N}$ & $\mathrm{N}$ & $\mathrm{N}$ & $\mathrm{N}$ & $\mathrm{N}$ & $\mathrm{N}$ & $\mathrm{N}$ & $\mathrm{N}$ & $\mathrm{Y}$ \\
\hline
\end{tabular}

Notes: All models include city, state, and calendar date fixed effects. Standard errors are clustered at the state level and reported in parentheses. The signs * and ** indicate statistical significance at 10 and 5 percent levels. 
Table 2. The effect of state level policies on pending sales

\begin{tabular}{|c|c|c|c|c|c|c|c|c|}
\hline & (1) & $(2)$ & (3) & (4) & (5) & (6) & $(7)$ & (8) \\
\hline Ban on mass gatherings & $\begin{array}{l}-0.006 \\
(0.048)\end{array}$ & $\begin{array}{l}-0.003 \\
(0.048)\end{array}$ & $\begin{array}{l}-0.008 \\
(0.047)\end{array}$ & $\begin{array}{l}-0.010 \\
(0.048)\end{array}$ & $\begin{array}{l}-0.006 \\
(0.048)\end{array}$ & $\begin{array}{l}-0.008 \\
(0.048)\end{array}$ & $\begin{array}{l}-0.007 \\
(0.049)\end{array}$ & $\begin{array}{c}0.027 \\
(0.044)\end{array}$ \\
\hline School closures & $\begin{array}{c}0.031 \\
(0.050)\end{array}$ & $\begin{array}{c}0.034 \\
(0.053)\end{array}$ & $\begin{array}{c}0.029 \\
(0.049)\end{array}$ & $\begin{array}{c}0.030 \\
(0.049)\end{array}$ & $\begin{array}{c}0.030 \\
(0.049)\end{array}$ & $\begin{array}{c}0.031 \\
(0.050)\end{array}$ & $\begin{array}{c}0.027 \\
(0.051)\end{array}$ & $\begin{array}{c}0.021 \\
(0.054)\end{array}$ \\
\hline Closure of any business & $\begin{array}{l}-0.024 \\
(0.034)\end{array}$ & $\begin{array}{l}-0.025 \\
(0.035)\end{array}$ & $\begin{array}{l}-0.024 \\
(0.033)\end{array}$ & $\begin{array}{l}-0.025 \\
(0.034)\end{array}$ & $\begin{array}{l}-0.024 \\
(0.033)\end{array}$ & $\begin{array}{l}-0.025 \\
(0.034)\end{array}$ & $\begin{array}{l}-0.019 \\
(0.034)\end{array}$ & $\begin{array}{l}-0.039 \\
(0.037)\end{array}$ \\
\hline Closure of non-essential business & $\begin{array}{l}-0.062 \\
(0.048)\end{array}$ & $\begin{array}{l}-0.044 \\
(0.050)\end{array}$ & $\begin{array}{l}-0.045 \\
(0.050)\end{array}$ & $\begin{array}{l}-0.049 \\
(0.049)\end{array}$ & $\begin{array}{l}-0.049 \\
(0.048)\end{array}$ & $\begin{array}{l}-0.052 \\
(0.049)\end{array}$ & $\begin{array}{l}-0.040 \\
(0.052)\end{array}$ & $\begin{array}{l}-0.022 \\
(0.059)\end{array}$ \\
\hline Stay at home order & $\begin{array}{c}0.011 \\
(0.036)\end{array}$ & $\begin{array}{l}-0.002 \\
(0.032)\end{array}$ & $\begin{array}{c}0.003 \\
(0.032)\end{array}$ & $\begin{array}{c}0.005 \\
(0.034)\end{array}$ & $\begin{array}{c}0.007 \\
(0.031)\end{array}$ & $\begin{array}{c}0.007 \\
(0.034)\end{array}$ & $\begin{array}{c}0.002 \\
(0.034)\end{array}$ & $\begin{array}{c}0.013 \\
(0.039)\end{array}$ \\
\hline Total cases per 10000 & & & $\begin{array}{c}-0.002 * \\
(0.001)\end{array}$ & & & & $\begin{array}{l}-0.002 \\
(0.001)\end{array}$ & $\begin{array}{l}-0.002 \\
(0.001)\end{array}$ \\
\hline Total deaths per 10000 & & & & $\begin{array}{c}-0.026 * * \\
(0.011)\end{array}$ & & & & \\
\hline New cases per 10000 & & & & & $\begin{array}{c}-0.023^{* *} \\
(0.009)\end{array}$ & & & \\
\hline New deaths per 10000 & & & & & & $\begin{array}{c}-0.196 * * \\
(0.085)\end{array}$ & & \\
\hline $\mathrm{N}$ & 2600 & 2600 & 2600 & 2600 & 2600 & 2600 & 2470 & 2145 \\
\hline Daily case count $\times$ calendar date & $\mathrm{N}$ & $\mathrm{Y}$ & $\mathrm{N}$ & $\mathrm{N}$ & $\mathrm{N}$ & $\mathrm{N}$ & $\mathrm{N}$ & $\mathrm{N}$ \\
\hline Drop NY & $\mathrm{N}$ & $\mathrm{N}$ & $\mathrm{N}$ & $\mathrm{N}$ & $\mathrm{N}$ & $\mathrm{N}$ & $\mathrm{Y}$ & $\mathrm{Y}$ \\
\hline Drop NY, WA, and CA & $\mathrm{N}$ & $\mathrm{N}$ & $\mathrm{N}$ & $\mathrm{N}$ & $\mathrm{N}$ & $\mathrm{N}$ & $\mathrm{N}$ & $\mathrm{Y}$ \\
\hline
\end{tabular}

Notes: All models include city, state, and calendar date fixed effects. Standard errors are clustered at the state level and reported in parentheses. The signs * and ** indicate statistical significance at 10 and 5 percent levels. 
Table 3. The effect of state level policies on web page views of for-sale homes

\begin{tabular}{|c|c|c|c|c|c|c|c|c|c|}
\hline & $(1)$ & $(2)$ & (3) & (4) & (5) & (6) & $(7)$ & (8) & (9) \\
\hline Ban on mass gatherings & $\begin{array}{c}0.013 \\
(0.015)\end{array}$ & $\begin{array}{c}0.013 \\
(0.013)\end{array}$ & $\begin{array}{c}0.011 \\
(0.013)\end{array}$ & $\begin{array}{c}0.010 \\
(0.014)\end{array}$ & $\begin{array}{c}0.012 \\
(0.013)\end{array}$ & $\begin{array}{c}0.012 \\
(0.014)\end{array}$ & $\begin{array}{c}0.008 \\
(0.013)\end{array}$ & $\begin{array}{c}0.007 \\
(0.014)\end{array}$ & $\begin{array}{c}0.012 \\
(0.014)\end{array}$ \\
\hline School closures & $\begin{array}{l}-0.020 \\
(0.015)\end{array}$ & $\begin{array}{l}-0.020 \\
(0.013)\end{array}$ & $\begin{array}{l}-0.021 \\
(0.014)\end{array}$ & $\begin{array}{l}-0.020 \\
(0.014)\end{array}$ & $\begin{array}{l}-0.021 \\
(0.014)\end{array}$ & $\begin{array}{l}-0.020 \\
(0.015)\end{array}$ & $\begin{array}{l}-0.018 \\
(0.013)\end{array}$ & $\begin{array}{l}-0.019 \\
(0.015)\end{array}$ & $\begin{array}{l}-0.020 \\
(0.014)\end{array}$ \\
\hline Closure of any business & $\begin{array}{c}0.001 \\
(0.016)\end{array}$ & $\begin{array}{l}-0.002 \\
(0.014)\end{array}$ & $\begin{array}{l}-0.002 \\
(0.014)\end{array}$ & $\begin{array}{l}-0.002 \\
(0.015)\end{array}$ & $\begin{array}{l}-0.001 \\
(0.014)\end{array}$ & $\begin{array}{l}-0.001 \\
(0.015)\end{array}$ & $\begin{array}{l}-0.003 \\
(0.014)\end{array}$ & $\begin{array}{l}-0.004 \\
(0.016)\end{array}$ & $\begin{array}{l}-0.008 \\
(0.013)\end{array}$ \\
\hline Closure of non-essential business & $\begin{array}{c}-0.072^{* *} \\
(0.034)\end{array}$ & $\begin{array}{c}-0.061 * \\
(0.031)\end{array}$ & $\begin{array}{c}-0.060 * \\
(0.031)\end{array}$ & $\begin{array}{l}-0.064 * \\
(0.033)\end{array}$ & $\begin{array}{c}-0.063^{*} \\
(0.031)\end{array}$ & $\begin{array}{c}-0.067 * \\
(0.033)\end{array}$ & $\begin{array}{l}-0.055^{*} \\
(0.031)\end{array}$ & $\begin{array}{l}-0.057 \\
(0.034)\end{array}$ & $\begin{array}{c}-0.064^{*} \\
(0.033)\end{array}$ \\
\hline Stay at home order & $\begin{array}{c}0.018 \\
(0.024)\end{array}$ & $\begin{array}{c}0.012 \\
(0.019)\end{array}$ & $\begin{array}{c}0.013 \\
(0.021)\end{array}$ & $\begin{array}{c}0.014 \\
(0.023)\end{array}$ & $\begin{array}{c}0.017 \\
(0.021)\end{array}$ & $\begin{array}{c}0.016 \\
(0.023)\end{array}$ & $\begin{array}{c}0.017 \\
(0.022)\end{array}$ & $\begin{array}{c}0.021 \\
(0.023)\end{array}$ & $\begin{array}{c}0.016 \\
(0.023)\end{array}$ \\
\hline Total cases per 10000 & & & $\begin{array}{c}-0.002 * \\
(0.001)\end{array}$ & & & & $\begin{array}{l}-0.002 \\
(0.001)\end{array}$ & $\begin{array}{l}-0.002 \\
(0.001)\end{array}$ & $\begin{array}{c}-0.002^{*} \\
(0.001)\end{array}$ \\
\hline Total deaths per 10000 & & & & $\begin{array}{c}-0.027 * * \\
(0.012)\end{array}$ & & & & & \\
\hline New cases per 10000 & & & & & $\begin{array}{c}-0.022^{* *} \\
(0.011)\end{array}$ & & & & \\
\hline New deaths per 10000 & & & & & & $\begin{array}{c}-0.148^{* *} \\
(0.065)\end{array}$ & & & \\
\hline $\mathrm{N}$ & 2300 & 2300 & 2300 & 2300 & 2300 & 2300 & 2208 & 1886 & 2254 \\
\hline Daily case count $\times$ calendar date & $\mathrm{N}$ & $\mathrm{Y}$ & $\mathrm{N}$ & $\mathrm{N}$ & $\mathrm{N}$ & $\mathrm{N}$ & $\mathrm{N}$ & $\mathrm{N}$ & $\mathrm{N}$ \\
\hline Drop NY & $\mathrm{N}$ & $\mathrm{N}$ & $\mathrm{N}$ & $\mathrm{N}$ & $\mathrm{N}$ & $\mathrm{N}$ & $\mathrm{Y}$ & Y & $\mathrm{N}$ \\
\hline Drop NY, WA, and CA & $\mathrm{N}$ & $\mathrm{N}$ & $\mathrm{N}$ & $\mathrm{N}$ & $\mathrm{N}$ & $\mathrm{N}$ & $\mathrm{N}$ & $\mathrm{Y}$ & $\mathrm{N}$ \\
\hline Drop KS and OK & $\mathrm{N}$ & $\mathrm{N}$ & $\mathrm{N}$ & $\mathrm{N}$ & $\mathrm{N}$ & $\mathrm{N}$ & $\mathrm{N}$ & $\mathrm{N}$ & $\mathrm{Y}$ \\
\hline
\end{tabular}

Notes: All models include city, state, and calendar date fixed effects. Standard errors are clustered at the state level and reported in parentheses. The signs * and ** indicate statistical significance at 10 and 5 percent levels. 
Figure 1. Change in new listings for selected cities

A. Northeast

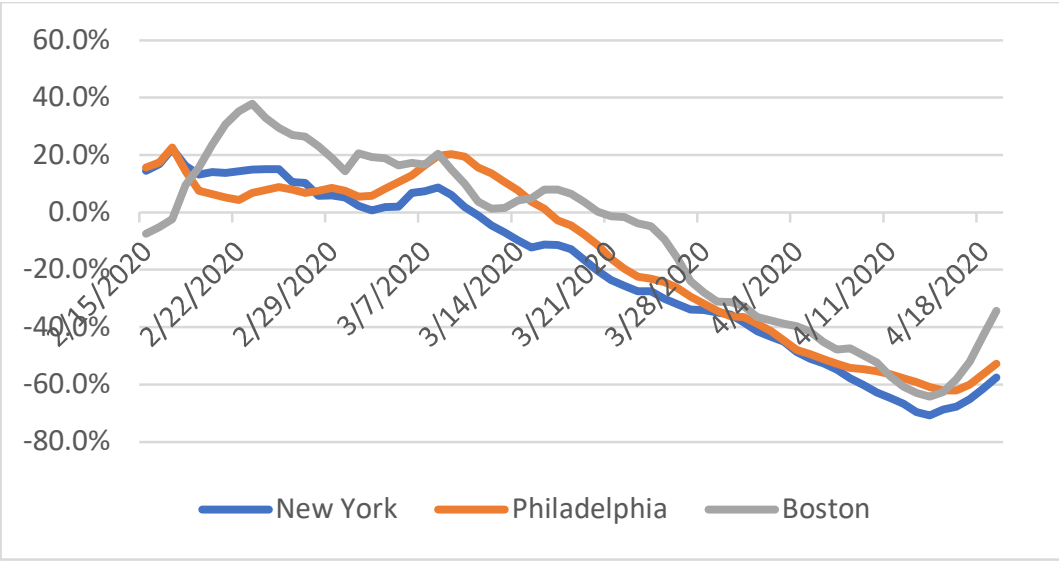

C. South

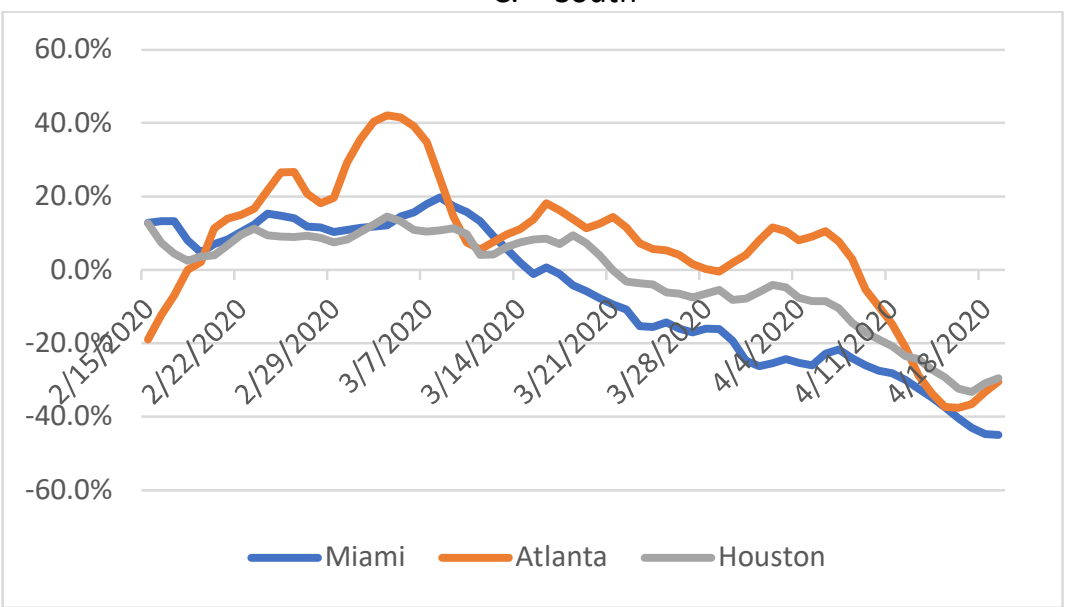

B. Midwest

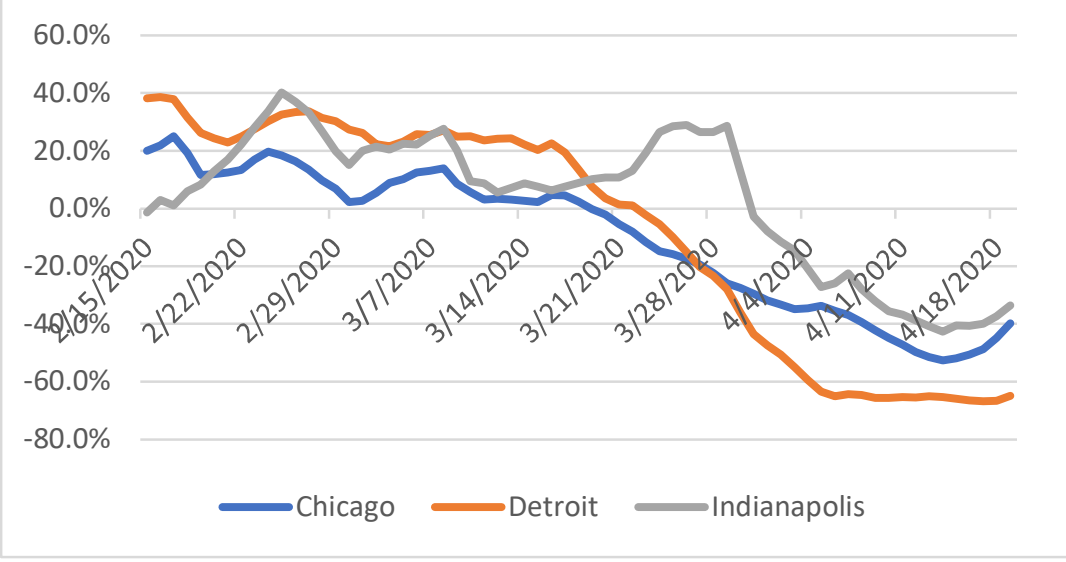

D. West

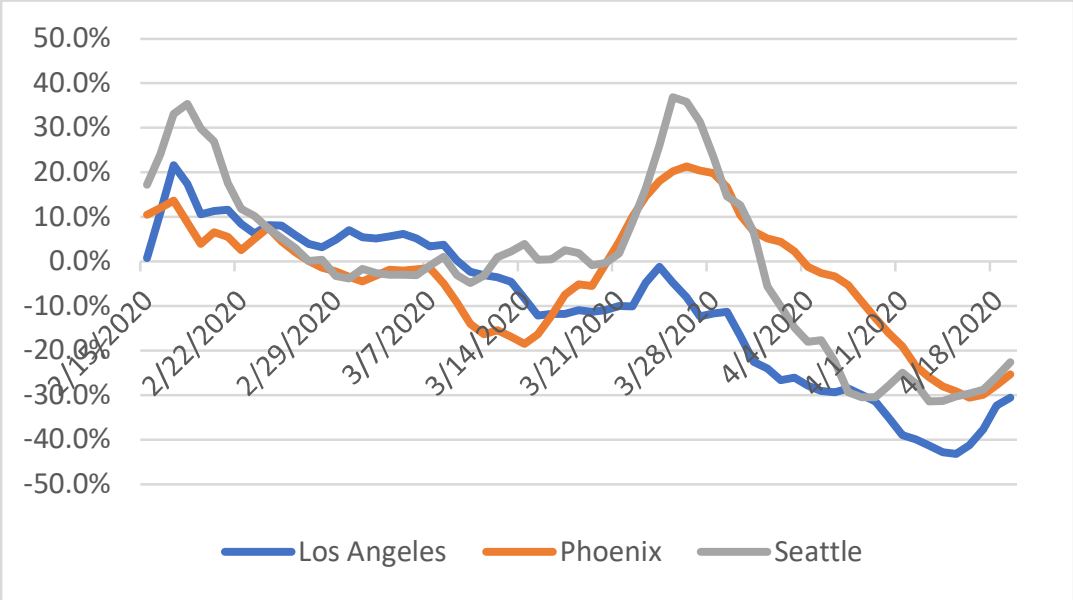

Notes: Percentage change in new listings are relative to the same time period in the previous year. 
Figure 2. Change in pending sales for selected cities

A. Northeast

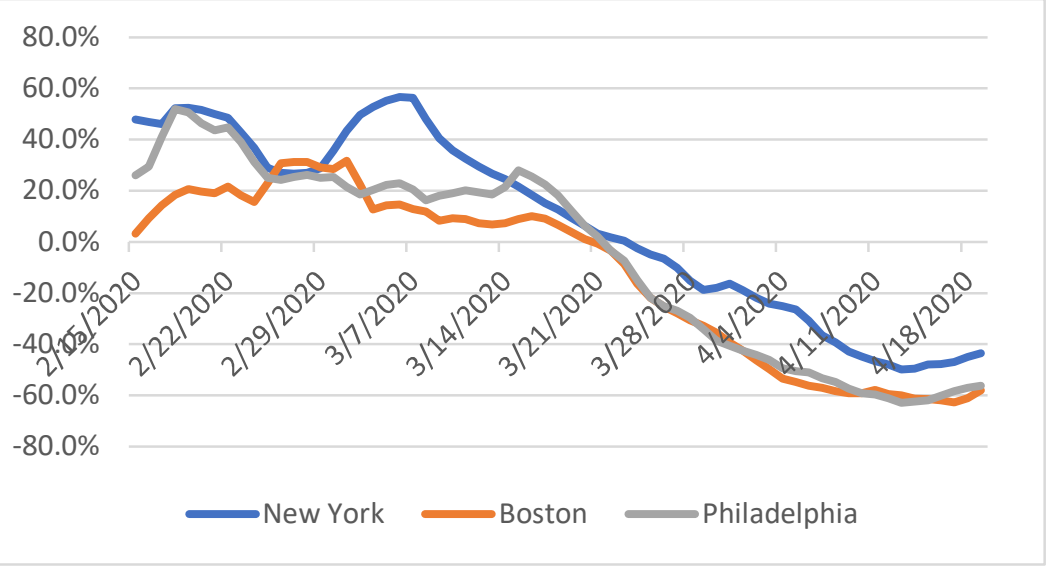

C. South

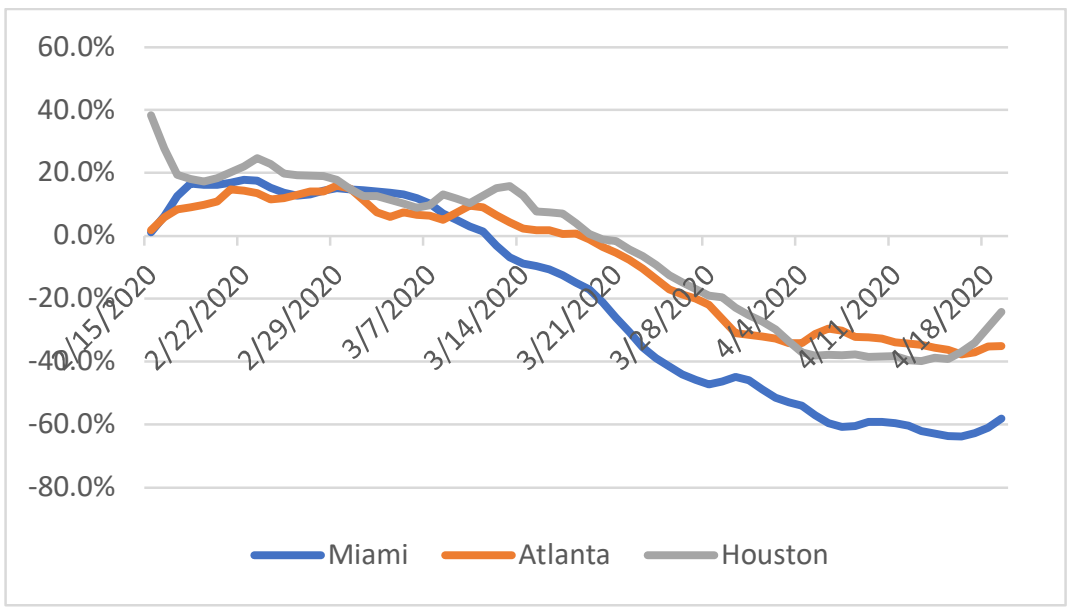

B. Midwest

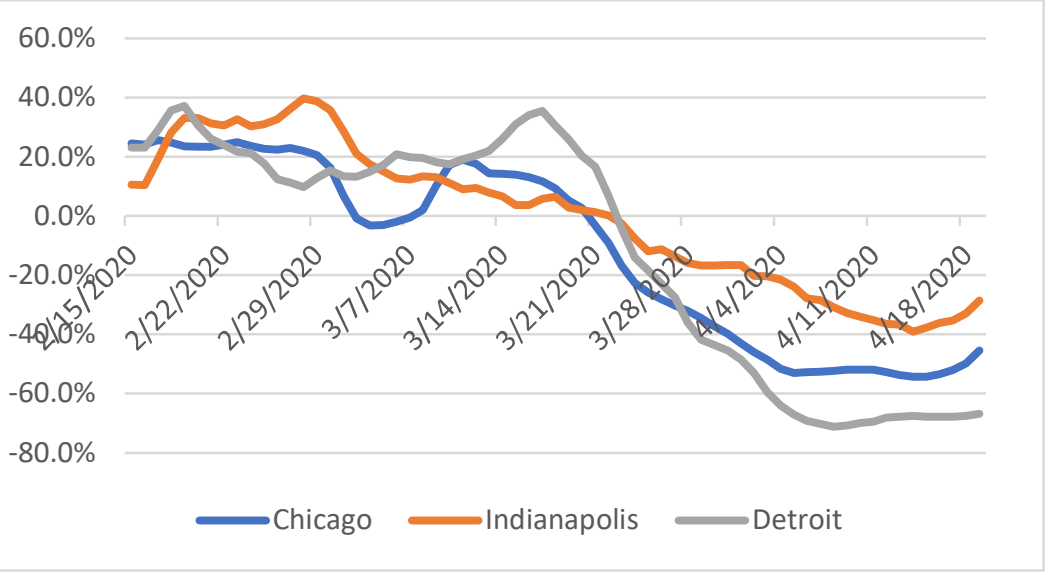

D. West

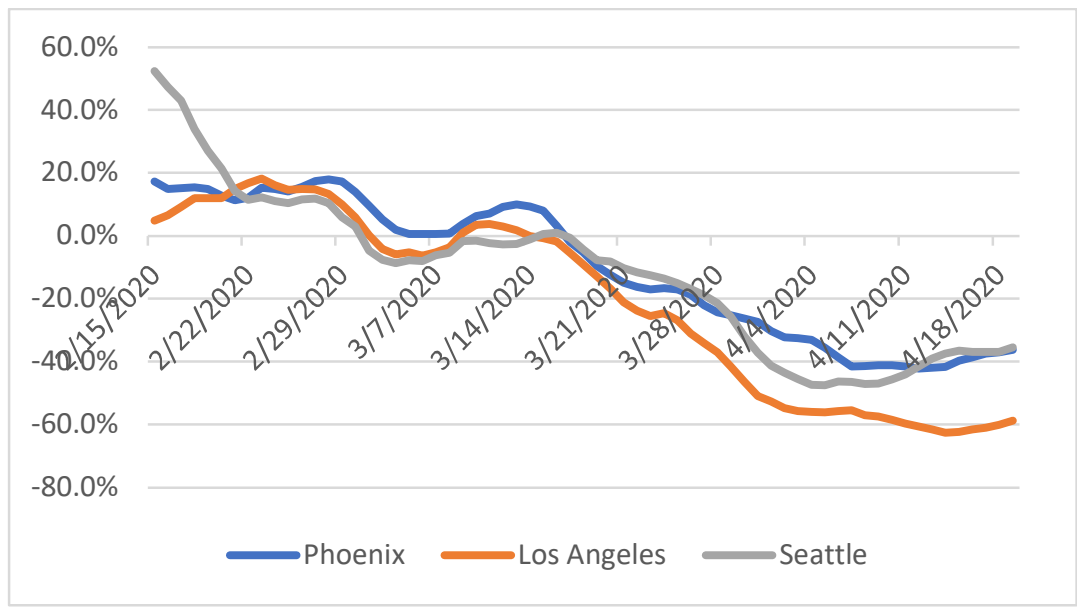

Notes: Percentage change in new listings are relative to the same time period in the previous year. 
Figure 3. Event study estimates of the impact of state policies on new listings and pending sales

A. Ban on mass gatherings

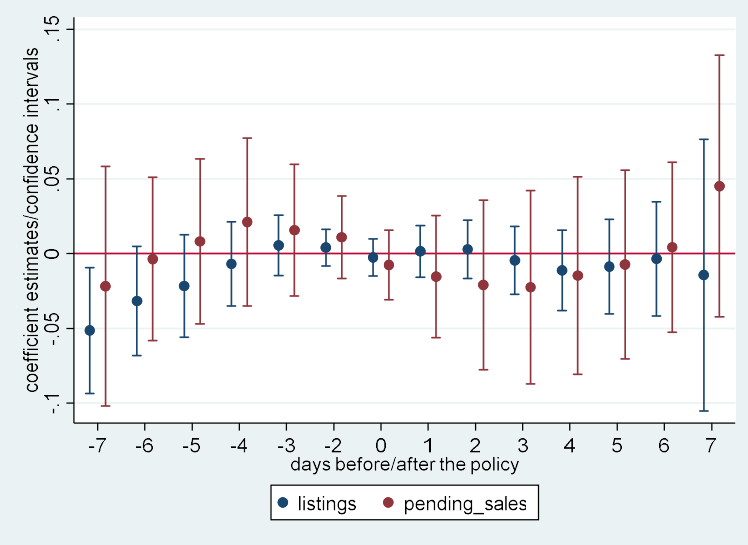

C. Closure of non-essential business

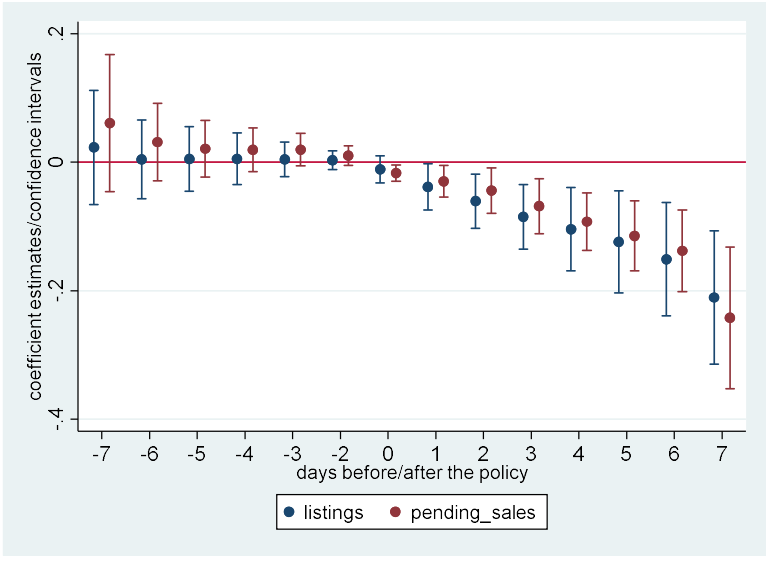

E. Stay at home orders

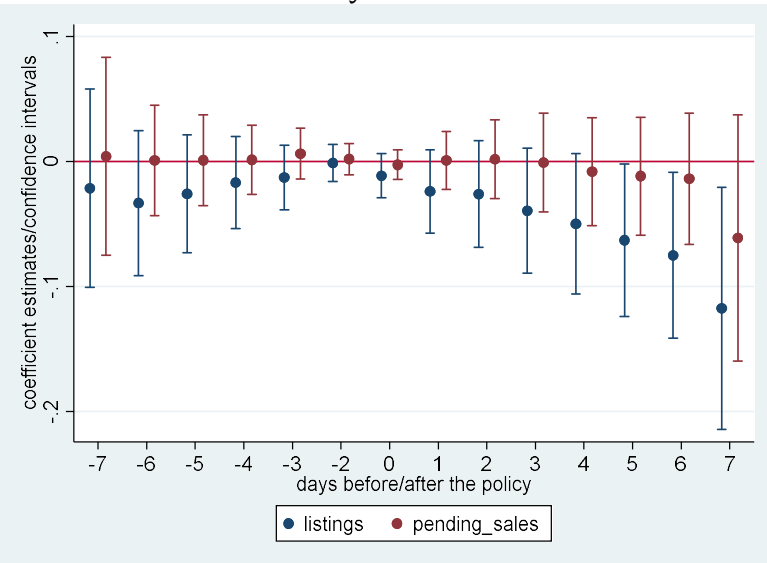

B. School closures

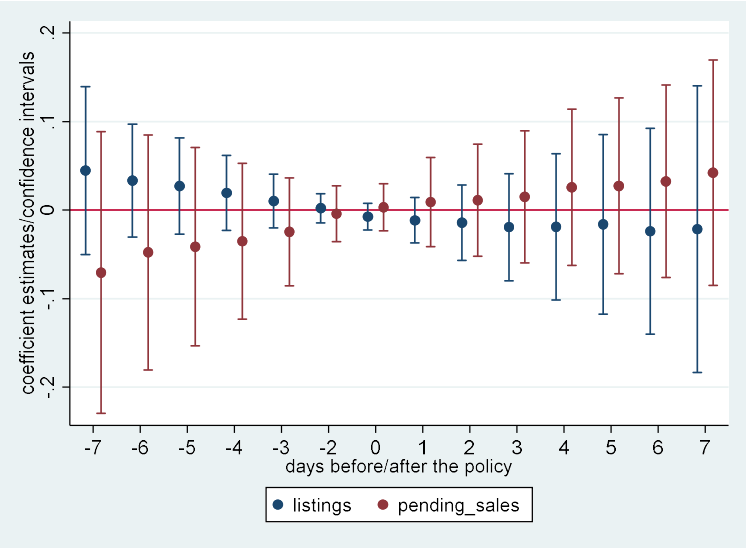

D. Any business closures

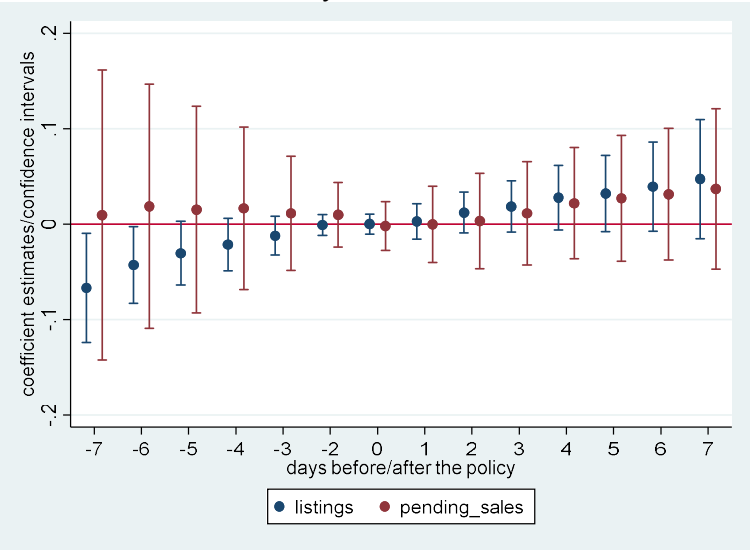

Notes: Coefficients with $95 \%$ confidence intervals from event study models as discussed in the text are plotted. The day prior to the announcement is excluded from the models. 


\section{Online Appendix}

Figure A1. Change in new listings, pending home sales, and web traffic to for-sale listings in the United States

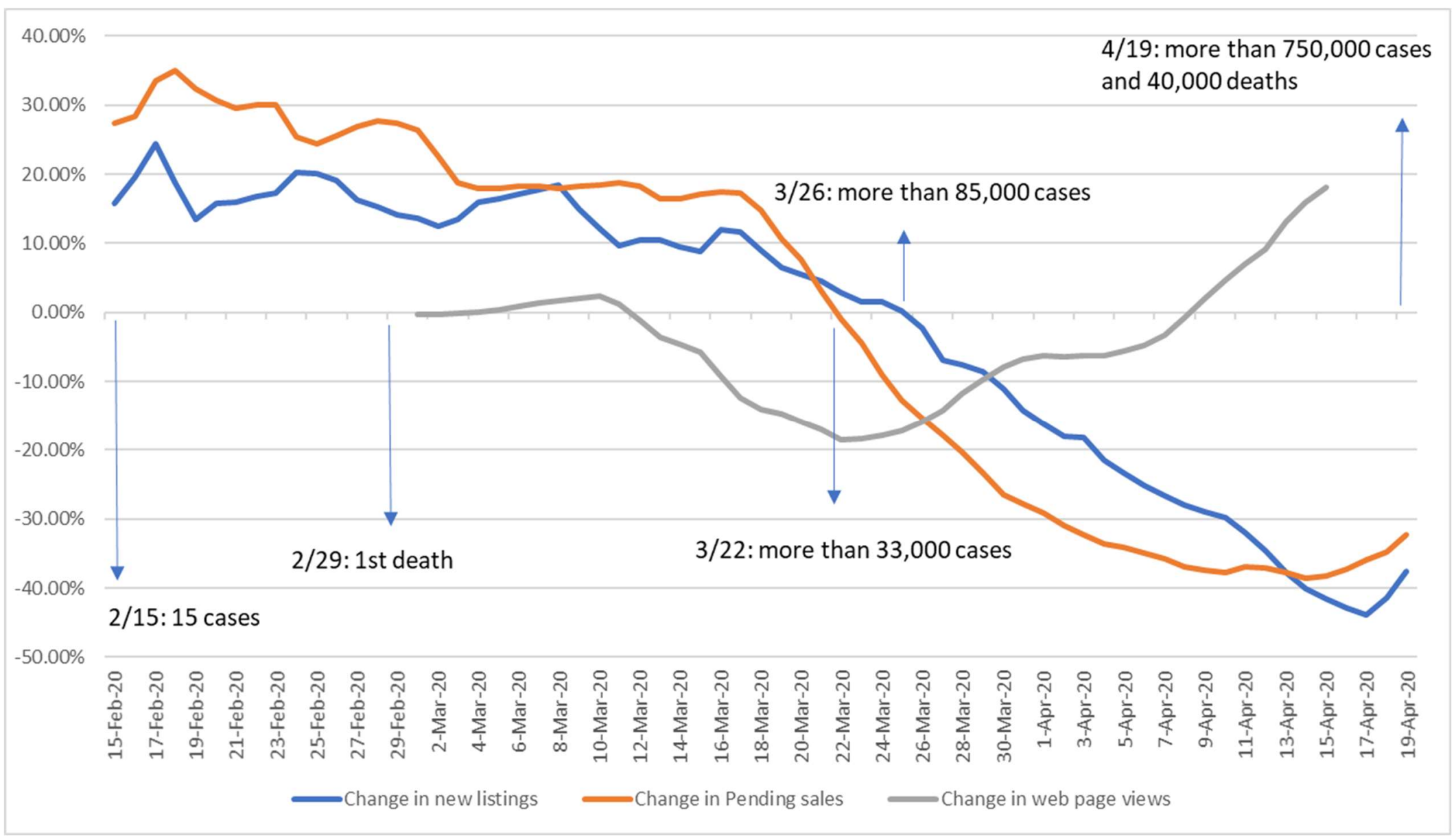

Notes: Percentage change in new listings and pending home sales are relative to the same time period in the previous year. Percentage change in web traffic to for-sale listings are relative to the same period in the previous year calculated as a 7-day moving average. Progress of the covid-19 pandemic in the United States is reported for certain dates. 
Table A1. Policy adoption date by city

\begin{tabular}{|c|c|c|c|c|c|c|}
\hline City & State & $\begin{array}{c}\text { Mass gatherings } \\
\text { ban }\end{array}$ & $\begin{array}{c}\text { School } \\
\text { closures }\end{array}$ & $\begin{array}{l}\text { Closure of non- } \\
\text { essential business }\end{array}$ & $\begin{array}{l}\text { Any business } \\
\text { closures }\end{array}$ & $\begin{array}{l}\text { Stay at home } \\
\text { orders }\end{array}$ \\
\hline Atlanta & GA & $3 / 24$ & $3 / 18$ & & $3 / 24$ & $4 / 3$ \\
\hline Austin & $\mathrm{TX}$ & $3 / 21$ & $3 / 19$ & & $3 / 21$ & $4 / 2$ \\
\hline Baltimore & MD & $3 / 16$ & $3 / 16$ & $3 / 23$ & $3 / 16$ & $3 / 30$ \\
\hline Birmingham & $\mathrm{AL}$ & $3 / 19$ & $3 / 19$ & $3 / 18$ & $3 / 19$ & $4 / 4$ \\
\hline Boston & MA & $3 / 13$ & $3 / 17$ & $3 / 24$ & $3 / 17$ & \\
\hline Buffalo & NY & $3 / 12$ & $3 / 18$ & $3 / 22$ & $3 / 16$ & $3 / 22$ \\
\hline Charlotte & NC & $3 / 14$ & $3 / 14$ & $3 / 30$ & $3 / 17$ & $3 / 30$ \\
\hline Chicago & $\mathrm{IL}$ & $3 / 13$ & $3 / 17$ & $3 / 21$ & $3 / 16$ & $3 / 21$ \\
\hline Cincinnati & $\mathrm{OH}$ & $3 / 12$ & $3 / 16$ & $3 / 23$ & $3 / 15$ & $3 / 23$ \\
\hline Cleveland & $\mathrm{OH}$ & $3 / 12$ & $3 / 16$ & $3 / 23$ & $3 / 15$ & $3 / 23$ \\
\hline Columbus & $\mathrm{OH}$ & $3 / 12$ & $3 / 16$ & $3 / 23$ & $3 / 15$ & $3 / 23$ \\
\hline Dallas-Fort Worth & $\mathrm{TX}$ & $3 / 21$ & $3 / 19$ & & $3 / 21$ & $4 / 2$ \\
\hline Denver & $\mathrm{CO}$ & $3 / 19$ & $3 / 23$ & $3 / 26$ & $3 / 17$ & $3 / 26$ \\
\hline Detroit & MI & $3 / 13$ & $3 / 16$ & $3 / 23$ & $3 / 16$ & $3 / 24$ \\
\hline Hartford & CT & $3 / 12$ & $3 / 17$ & $3 / 23$ & $3 / 16$ & \\
\hline Houston & TX & $3 / 21$ & $3 / 19$ & & $3 / 21$ & $4 / 2$ \\
\hline Indianapolis & IN & $3 / 12$ & $3 / 19$ & $3 / 24$ & $3 / 16$ & $3 / 25$ \\
\hline Jacksonville & FL & $4 / 3$ & $3 / 17$ & & $3 / 17$ & $4 / 3$ \\
\hline Kansas City & $\mathrm{MO}$ & $3 / 19$ & $3 / 23$ & & $3 / 23$ & $4 / 6$ \\
\hline Las Vegas & NV & $3 / 24$ & $3 / 16$ & $3 / 21$ & $3 / 18$ & $3 / 31$ \\
\hline Los Angeles & CA & $3 / 11$ & $3 / 19$ & $3 / 19$ & $3 / 19$ & $3 / 19$ \\
\hline Louisville & $\mathrm{KY}$ & $3 / 19$ & $3 / 20$ & $3 / 26$ & $3 / 16$ & \\
\hline Memphis & $\mathrm{TN}$ & $3 / 23$ & $3 / 20$ & $4 / 1$ & $3 / 23$ & $4 / 2$ \\
\hline Miami & FL & $4 / 3$ & $3 / 17$ & & $3 / 17$ & $4 / 3$ \\
\hline Milwaukee & WI & $3 / 23$ & $3 / 18$ & $3 / 25$ & $3 / 17$ & $3 / 25$ \\
\hline Minneapolis & $\mathrm{MN}$ & $3 / 24$ & $3 / 18$ & & $3 / 17$ & $3 / 27$ \\
\hline Nashville & $\mathrm{TN}$ & $3 / 23$ & $3 / 20$ & $4 / 1$ & $3 / 23$ & $4 / 2$ \\
\hline New Orleans & LA & $3 / 13$ & $3 / 16$ & $3 / 22$ & $3 / 17$ & $3 / 23$ \\
\hline New York City & NY & $3 / 12$ & $3 / 18$ & $3 / 22$ & $3 / 16$ & $3 / 22$ \\
\hline Oklahoma City & OK & $3 / 24$ & $3 / 17$ & $4 / 1$ & $4 / 1$ & \\
\hline Orlando & FL & $4 / 3$ & $3 / 17$ & & $3 / 17$ & $4 / 3$ \\
\hline Philadelphia & PA & $4 / 1$ & $3 / 17$ & $3 / 23$ & $3 / 18$ & $4 / 1$ \\
\hline Phoenix & AZ & $3 / 30$ & $3 / 16$ & & & $3 / 30$ \\
\hline Pittsburgh & PA & $4 / 1$ & $3 / 17$ & $3 / 23$ & $3 / 18$ & $4 / 1$ \\
\hline Portland & OR & $3 / 12$ & $3 / 16$ & & $3 / 17$ & $3 / 23$ \\
\hline Providence & RI & $3 / 17$ & $3 / 16$ & & $3 / 17$ & $3 / 28$ \\
\hline Raleigh & $\mathrm{NC}$ & $3 / 14$ & $3 / 14$ & $3 / 30$ & $3 / 17$ & $3 / 30$ \\
\hline Richmond & $\mathrm{NC}$ & $3 / 14$ & $3 / 14$ & $3 / 30$ & $3 / 17$ & $3 / 30$ \\
\hline Riverside & CA & $3 / 11$ & $3 / 19$ & $3 / 19$ & $3 / 19$ & $3 / 19$ \\
\hline Sacramento & CA & $3 / 11$ & $3 / 19$ & $3 / 19$ & $3 / 19$ & $3 / 19$ \\
\hline Salt Lake City & UT & $3 / 19$ & $3 / 16$ & & $3 / 19$ & \\
\hline San Antonio & $\mathrm{TX}$ & $3 / 21$ & $3 / 19$ & & $3 / 21$ & $4 / 2$ \\
\hline San Diego & CA & $3 / 11$ & $3 / 19$ & $3 / 19$ & $3 / 19$ & $3 / 19$ \\
\hline San Francisco & CA & $3 / 11$ & $3 / 19$ & $3 / 19$ & $3 / 19$ & $3 / 19$ \\
\hline San Jose & CA & $3 / 11$ & $3 / 19$ & $3 / 19$ & $3 / 19$ & $3 / 19$ \\
\hline Seattle & WA & $3 / 11$ & $3 / 13$ & $3 / 25$ & $3 / 16$ & $3 / 23$ \\
\hline St. Louis & MO & $3 / 23$ & $3 / 23$ & & $3 / 23$ & $4 / 6$ \\
\hline Tampa & FL & $4 / 3$ & $3 / 17$ & & $3 / 17$ & $4 / 3$ \\
\hline Virginia Beach & VA & $3 / 15$ & $3 / 16$ & $3 / 24$ & $3 / 17$ & $3 / 30$ \\
\hline Washington & DC & $3 / 13$ & $3 / 16$ & $3 / 25$ & $3 / 16$ & $3 / 30$ \\
\hline
\end{tabular}


Table A2. Summary statistics

\begin{tabular}{|c|c|}
\hline $\begin{array}{c}\text { No. of } \\
\text { Obs. }\end{array}$ & Mean \\
\hline
\end{tabular}

\section{Outcome variables}

Percentage change in the no. of newly listed homes (relative to the same time period in 2019)

$\begin{array}{lll}3250 & -0.025 & 0.239\end{array}$

Percentage change in the no. of pending home sales (relative to the same time period in 2019)

$\begin{array}{lll}2600 & -0.061 & 0.298\end{array}$

Percentage change in web traffic to for-sale homes (7-day

moving average relative to the same time period in 2019)

$\begin{array}{lll}2300 & -0.048 & 0.130\end{array}$

\section{Controls for spread of the COVID-19}

Total number of cases (per 10,000 people at county level)

$\begin{array}{lll}3250 & 5.436 & 15.657 \\ 3250 & 0.201 & 0.891 \\ 3250 & 0.387 & 1.042 \\ 3250 & 0.019 & 0.097\end{array}$

Daily new deaths (per 10,000 people at county level)

\section{State level policies to combat COVID-19}

Bans on mass gatherings

$\begin{array}{lll}3250 & 0.498 & 0.500\end{array}$

Any business closures

$\begin{array}{lll}3250 & 0.493 \quad 0.500\end{array}$

School closures

$\begin{array}{lll}3250 & 0.513 & 0.500\end{array}$

Closure of non-essential business

$\begin{array}{lll}3250 & 0.283 & 0.451\end{array}$

Stay-at-home orders

$\begin{array}{lll}3250 & 0.320 \quad 0.467\end{array}$


Table A3. Event study estimates: Restrictions on mass gatherings

\begin{tabular}{|c|c|c|c|c|c|c|c|c|c|}
\hline \multirow[b]{2}{*}{$\begin{array}{l}\text { No. of days to } \\
\text { policy }\end{array}$} & \multicolumn{5}{|c|}{ Percentage change in new listings } & \multicolumn{4}{|c|}{ Percentage change in pending sales } \\
\hline & (1) & (2) & (3) & (4) & (5) & (1) & (2) & (3) & (4) \\
\hline-7 & $\begin{array}{c}-0.051 * * \\
(0.021)\end{array}$ & $\begin{array}{c}-0.045^{* *} \\
(0.019)\end{array}$ & $\begin{array}{c}-0.042^{* *} \\
(0.019)\end{array}$ & $\begin{array}{c}-0.050^{* *} \\
(0.019)\end{array}$ & $\begin{array}{c}-0.049 * * \\
(0.020)\end{array}$ & $\begin{array}{l}-0.022 \\
(0.039)\end{array}$ & $\begin{array}{l}-0.014 \\
(0.037)\end{array}$ & $\begin{array}{l}-0.006 \\
(0.036)\end{array}$ & $\begin{array}{l}-0.027 \\
(0.040)\end{array}$ \\
\hline-6 & $\begin{array}{l}-0.032^{*} \\
(0.018)\end{array}$ & $\begin{array}{l}-0.030^{*} \\
(0.017)\end{array}$ & $\begin{array}{l}-0.027 \\
(0.018)\end{array}$ & $\begin{array}{c}-0.040^{* *} \\
(0.017)\end{array}$ & $\begin{array}{l}-0.031^{*} \\
(0.018)\end{array}$ & $\begin{array}{l}-0.004 \\
(0.027)\end{array}$ & $\begin{array}{l}-0.001 \\
(0.027)\end{array}$ & $\begin{array}{l}-0.001 \\
(0.027)\end{array}$ & $\begin{array}{l}-0.012 \\
(0.029)\end{array}$ \\
\hline-5 & $\begin{array}{l}-0.022 \\
(0.017)\end{array}$ & $\begin{array}{l}-0.020 \\
(0.017)\end{array}$ & $\begin{array}{l}-0.016 \\
(0.017)\end{array}$ & $\begin{array}{l}-0.026 \\
(0.017)\end{array}$ & $\begin{array}{l}-0.020 \\
(0.017)\end{array}$ & $\begin{array}{c}0.008 \\
(0.027)\end{array}$ & $\begin{array}{c}0.010 \\
(0.027)\end{array}$ & $\begin{array}{c}0.008 \\
(0.027)\end{array}$ & $\begin{array}{c}0.001 \\
(0.029)\end{array}$ \\
\hline-4 & $\begin{array}{l}-0.007 \\
(0.014)\end{array}$ & $\begin{array}{l}-0.006 \\
(0.014)\end{array}$ & $\begin{array}{l}-0.003 \\
(0.014)\end{array}$ & $\begin{array}{l}-0.011 \\
(0.014)\end{array}$ & $\begin{array}{l}-0.006 \\
(0.014)\end{array}$ & $\begin{array}{c}0.021 \\
(0.027)\end{array}$ & $\begin{array}{c}0.022 \\
(0.028)\end{array}$ & $\begin{array}{c}0.021 \\
(0.028)\end{array}$ & $\begin{array}{c}0.017 \\
(0.030)\end{array}$ \\
\hline-3 & $\begin{array}{c}0.006 \\
(0.010)\end{array}$ & $\begin{array}{c}0.006 \\
(0.010)\end{array}$ & $\begin{array}{c}0.008 \\
(0.010)\end{array}$ & $\begin{array}{c}0.002 \\
(0.010)\end{array}$ & $\begin{array}{c}0.007 \\
(0.010)\end{array}$ & $\begin{array}{c}0.016 \\
(0.021)\end{array}$ & $\begin{array}{c}0.017 \\
(0.022)\end{array}$ & $\begin{array}{c}0.016 \\
(0.022)\end{array}$ & $\begin{array}{c}0.014 \\
(0.023)\end{array}$ \\
\hline-2 & $\begin{array}{c}0.004 \\
(0.006)\end{array}$ & $\begin{array}{c}0.004 \\
(0.006)\end{array}$ & $\begin{array}{c}0.004 \\
(0.006)\end{array}$ & $\begin{array}{c}0.000 \\
(0.006)\end{array}$ & $\begin{array}{c}0.004 \\
(0.006)\end{array}$ & $\begin{array}{c}0.011 \\
(0.013)\end{array}$ & $\begin{array}{c}0.010 \\
(0.014)\end{array}$ & $\begin{array}{c}0.010 \\
(0.014)\end{array}$ & $\begin{array}{c}0.010 \\
(0.015)\end{array}$ \\
\hline 0 & $\begin{array}{l}-0.003 \\
(0.006)\end{array}$ & $\begin{array}{l}-0.003 \\
(0.006)\end{array}$ & $\begin{array}{l}-0.004 \\
(0.006)\end{array}$ & $\begin{array}{l}-0.001 \\
(0.006)\end{array}$ & $\begin{array}{l}-0.004 \\
(0.006)\end{array}$ & $\begin{array}{l}-0.008 \\
(0.011)\end{array}$ & $\begin{array}{l}-0.009 \\
(0.011)\end{array}$ & $\begin{array}{l}-0.008 \\
(0.011)\end{array}$ & $\begin{array}{l}-0.006 \\
(0.011)\end{array}$ \\
\hline 1 & $\begin{array}{c}0.002 \\
(0.008)\end{array}$ & $\begin{array}{c}0.000 \\
(0.008)\end{array}$ & $\begin{array}{l}-0.001 \\
(0.008)\end{array}$ & $\begin{array}{c}0.004 \\
(0.008)\end{array}$ & $\begin{array}{l}-0.001 \\
(0.009)\end{array}$ & $\begin{array}{l}-0.015 \\
(0.020)\end{array}$ & $\begin{array}{l}-0.017 \\
(0.020)\end{array}$ & $\begin{array}{l}-0.016 \\
(0.020)\end{array}$ & $\begin{array}{l}-0.011 \\
(0.019)\end{array}$ \\
\hline 2 & $\begin{array}{c}0.003 \\
(0.010)\end{array}$ & $\begin{array}{c}0.001 \\
(0.010)\end{array}$ & $\begin{array}{l}-0.001 \\
(0.009)\end{array}$ & $\begin{array}{c}0.003 \\
(0.010)\end{array}$ & $\begin{array}{l}-0.001 \\
(0.009)\end{array}$ & $\begin{array}{l}-0.021 \\
(0.028)\end{array}$ & $\begin{array}{l}-0.023 \\
(0.027)\end{array}$ & $\begin{array}{l}-0.022 \\
(0.028)\end{array}$ & $\begin{array}{l}-0.013 \\
(0.026)\end{array}$ \\
\hline 3 & $\begin{array}{l}-0.005 \\
(0.011)\end{array}$ & $\begin{array}{l}-0.006 \\
(0.011)\end{array}$ & $\begin{array}{l}-0.007 \\
(0.012)\end{array}$ & $\begin{array}{l}-0.002 \\
(0.012)\end{array}$ & $\begin{array}{l}-0.010 \\
(0.011)\end{array}$ & $\begin{array}{l}-0.023 \\
(0.031)\end{array}$ & $\begin{array}{l}-0.024 \\
(0.031)\end{array}$ & $\begin{array}{l}-0.022 \\
(0.031)\end{array}$ & $\begin{array}{l}-0.007 \\
(0.029)\end{array}$ \\
\hline 4 & $\begin{array}{l}-0.011 \\
(0.013)\end{array}$ & $\begin{array}{l}-0.014 \\
(0.014)\end{array}$ & $\begin{array}{l}-0.016 \\
(0.014)\end{array}$ & $\begin{array}{l}-0.008 \\
(0.015)\end{array}$ & $\begin{array}{l}-0.018 \\
(0.013)\end{array}$ & $\begin{array}{l}-0.015 \\
(0.032)\end{array}$ & $\begin{array}{l}-0.018 \\
(0.031)\end{array}$ & $\begin{array}{l}-0.014 \\
(0.031)\end{array}$ & $\begin{array}{c}0.002 \\
(0.028)\end{array}$ \\
\hline 5 & $\begin{array}{l}-0.009 \\
(0.015)\end{array}$ & $\begin{array}{l}-0.012 \\
(0.016)\end{array}$ & $\begin{array}{l}-0.013 \\
(0.016)\end{array}$ & $\begin{array}{l}-0.004 \\
(0.017)\end{array}$ & $\begin{array}{l}-0.017 \\
(0.016)\end{array}$ & $\begin{array}{l}-0.007 \\
(0.031)\end{array}$ & $\begin{array}{l}-0.011 \\
(0.030)\end{array}$ & $\begin{array}{l}-0.007 \\
(0.030)\end{array}$ & $\begin{array}{c}0.009 \\
(0.026)\end{array}$ \\
\hline 6 & $\begin{array}{l}-0.004 \\
(0.019)\end{array}$ & $\begin{array}{l}-0.005 \\
(0.019)\end{array}$ & $\begin{array}{l}-0.006 \\
(0.020)\end{array}$ & $\begin{array}{l}0.005 \\
(0.022)\end{array}$ & $\begin{array}{l}-0.009 \\
(0.019)\end{array}$ & $\begin{array}{c}0.004 \\
(0.028)\end{array}$ & $\begin{array}{c}0.002 \\
(0.027)\end{array}$ & $\begin{array}{c}0.007 \\
(0.028)\end{array}$ & $\begin{array}{c}0.027 \\
(0.023)\end{array}$ \\
\hline 7 & $\begin{array}{c}-0.014 \\
(0.044) \\
\end{array}$ & $\begin{array}{c}-0.014 \\
(0.044) \\
\end{array}$ & $\begin{array}{l}-0.009 \\
(0.046) \\
\end{array}$ & $\begin{array}{c}0.012 \\
(0.050) \\
\end{array}$ & $\begin{array}{r}-0.020 \\
(0.045) \\
\end{array}$ & $\begin{array}{c}0.045 \\
(0.043) \\
\end{array}$ & $\begin{array}{c}0.044 \\
(0.043) \\
\end{array}$ & $\begin{array}{c}0.047 \\
(0.046) \\
\end{array}$ & $\begin{array}{c}0.087^{* *} \\
(0.035) \\
\end{array}$ \\
\hline $\mathrm{N}$ & 3250 & 3250 & 3120 & 2665 & 3185 & 2600 & 2600 & 2470 & 2145 \\
\hline $\begin{array}{l}\text { Daily new cases \& } \\
\text { deaths per capita }\end{array}$ & $\mathrm{N}$ & Y & Y & Y & Y & $\mathrm{N}$ & Y & Y & $\mathrm{Y}$ \\
\hline Drop NY & $\mathrm{N}$ & $\mathrm{N}$ & Y & $\mathrm{Y}$ & $\mathrm{N}$ & $\mathrm{N}$ & $\mathrm{N}$ & $\mathrm{Y}$ & Y \\
\hline Drop NY, CA, WA & $\mathrm{N}$ & $\mathrm{N}$ & $\mathrm{N}$ & $\mathrm{Y}$ & $\mathrm{N}$ & $\mathrm{N}$ & $\mathrm{N}$ & $\mathrm{N}$ & $\mathrm{Y}$ \\
\hline Drop KS and OK & $\mathrm{N}$ & $\mathrm{N}$ & $\mathrm{N}$ & $\mathrm{N}$ & $\mathrm{Y}$ & $\mathrm{N}$ & $\mathrm{N}$ & $\mathrm{N}$ & $\mathrm{N}$ \\
\hline
\end{tabular}

Notes: The day prior the announcement of the policy is the excluded category. All models include city, state, and calendar date fixed effects. Standard errors are clustered at the state level and reported in parentheses. The signs * and ** indicate statistical significance at 10 and 5 percent levels. 
Table A4. Event study estimates: School closures

\begin{tabular}{|c|c|c|c|c|c|c|c|c|c|}
\hline \multirow[b]{2}{*}{$\begin{array}{l}\text { No. of days to } \\
\text { policy }\end{array}$} & \multicolumn{5}{|c|}{ Percentage change in new listings } & \multicolumn{4}{|c|}{ Percentage change in pending sales } \\
\hline & (1) & (2) & (3) & (4) & (5) & (1) & (2) & (3) & (4) \\
\hline-7 & $\begin{array}{c}0.045 \\
(0.046)\end{array}$ & $\begin{array}{c}0.050 \\
(0.043)\end{array}$ & $\begin{array}{c}0.048 \\
(0.042)\end{array}$ & $\begin{array}{c}0.035 \\
(0.044)\end{array}$ & $\begin{array}{c}0.049 \\
(0.043)\end{array}$ & $\begin{array}{l}-0.071 \\
(0.077)\end{array}$ & $\begin{array}{l}-0.065 \\
(0.075)\end{array}$ & $\begin{array}{l}-0.070 \\
(0.074)\end{array}$ & $\begin{array}{l}-0.092 \\
(0.078)\end{array}$ \\
\hline-6 & $\begin{array}{c}0.033 \\
(0.031)\end{array}$ & $\begin{array}{c}0.037 \\
(0.029)\end{array}$ & $\begin{array}{c}0.033 \\
(0.028)\end{array}$ & $\begin{array}{c}0.032 \\
(0.031)\end{array}$ & $\begin{array}{c}0.036 \\
(0.029)\end{array}$ & $\begin{array}{l}-0.048 \\
(0.065)\end{array}$ & $\begin{array}{l}-0.044 \\
(0.063)\end{array}$ & $\begin{array}{l}-0.047 \\
(0.063)\end{array}$ & $\begin{array}{l}-0.057 \\
(0.069)\end{array}$ \\
\hline-5 & $\begin{array}{c}0.027 \\
(0.027)\end{array}$ & $\begin{array}{c}0.030 \\
(0.025)\end{array}$ & $\begin{array}{c}0.027 \\
(0.025)\end{array}$ & $\begin{array}{c}0.028 \\
(0.027)\end{array}$ & $\begin{array}{c}0.029 \\
(0.025)\end{array}$ & $\begin{array}{l}-0.041 \\
(0.054)\end{array}$ & $\begin{array}{l}-0.039 \\
(0.053)\end{array}$ & $\begin{array}{l}-0.041 \\
(0.053)\end{array}$ & $\begin{array}{l}-0.047 \\
(0.059)\end{array}$ \\
\hline-4 & $\begin{array}{c}0.019 \\
(0.021)\end{array}$ & $\begin{array}{c}0.022 \\
(0.020)\end{array}$ & $\begin{array}{c}0.019 \\
(0.019)\end{array}$ & $\begin{array}{c}0.022 \\
(0.021)\end{array}$ & $\begin{array}{c}0.021 \\
(0.020)\end{array}$ & $\begin{array}{l}-0.035 \\
(0.043)\end{array}$ & $\begin{array}{l}-0.033 \\
(0.042)\end{array}$ & $\begin{array}{l}-0.035 \\
(0.042)\end{array}$ & $\begin{array}{l}-0.041 \\
(0.046)\end{array}$ \\
\hline-3 & $\begin{array}{c}0.010 \\
(0.015)\end{array}$ & $\begin{array}{c}0.012 \\
(0.014)\end{array}$ & $\begin{array}{c}0.011 \\
(0.014)\end{array}$ & $\begin{array}{c}0.015 \\
(0.016)\end{array}$ & $\begin{array}{c}0.011 \\
(0.014)\end{array}$ & $\begin{array}{l}-0.024 \\
(0.030)\end{array}$ & $\begin{array}{l}-0.023 \\
(0.029)\end{array}$ & $\begin{array}{l}-0.025 \\
(0.029)\end{array}$ & $\begin{array}{l}-0.030 \\
(0.032)\end{array}$ \\
\hline-2 & $\begin{array}{c}0.002 \\
(0.008)\end{array}$ & $\begin{array}{c}0.003 \\
(0.008)\end{array}$ & $\begin{array}{c}0.003 \\
(0.008)\end{array}$ & $\begin{array}{c}0.004 \\
(0.009)\end{array}$ & $\begin{array}{c}0.003 \\
(0.008)\end{array}$ & $\begin{array}{l}-0.004 \\
(0.015)\end{array}$ & $\begin{array}{l}-0.003 \\
(0.015)\end{array}$ & $\begin{array}{l}-0.003 \\
(0.015)\end{array}$ & $\begin{array}{l}-0.005 \\
(0.017)\end{array}$ \\
\hline 0 & $\begin{array}{l}-0.007 \\
(0.007)\end{array}$ & $\begin{array}{l}-0.007 \\
(0.008)\end{array}$ & $\begin{array}{l}-0.009 \\
(0.007)\end{array}$ & $\begin{array}{l}-0.007 \\
(0.009)\end{array}$ & $\begin{array}{l}-0.007 \\
(0.008)\end{array}$ & $\begin{array}{c}0.003 \\
(0.013)\end{array}$ & $\begin{array}{c}0.003 \\
(0.012)\end{array}$ & $\begin{array}{c}0.002 \\
(0.012)\end{array}$ & $\begin{array}{l}0.002 \\
(0.013)\end{array}$ \\
\hline 1 & $\begin{array}{l}-0.012 \\
(0.013)\end{array}$ & $\begin{array}{l}-0.012 \\
(0.013)\end{array}$ & $\begin{array}{l}-0.013 \\
(0.013)\end{array}$ & $\begin{array}{l}-0.009 \\
(0.015)\end{array}$ & $\begin{array}{l}-0.011 \\
(0.013)\end{array}$ & $\begin{array}{c}0.009 \\
(0.024)\end{array}$ & $\begin{array}{c}0.009 \\
(0.024)\end{array}$ & $\begin{array}{c}0.005 \\
(0.023)\end{array}$ & $\begin{array}{l}0.005 \\
(0.025)\end{array}$ \\
\hline 2 & $\begin{array}{l}-0.014 \\
(0.021)\end{array}$ & $\begin{array}{l}-0.016 \\
(0.021)\end{array}$ & $\begin{array}{l}-0.016 \\
(0.021)\end{array}$ & $\begin{array}{l}-0.014 \\
(0.023)\end{array}$ & $\begin{array}{l}-0.015 \\
(0.021)\end{array}$ & $\begin{array}{c}0.011 \\
(0.031)\end{array}$ & $\begin{array}{c}0.009 \\
(0.030)\end{array}$ & $\begin{array}{c}0.007 \\
(0.029)\end{array}$ & $\begin{array}{l}0.004 \\
(0.031)\end{array}$ \\
\hline 3 & $\begin{array}{l}-0.019 \\
(0.030)\end{array}$ & $\begin{array}{l}-0.020 \\
(0.030)\end{array}$ & $\begin{array}{l}-0.021 \\
(0.030)\end{array}$ & $\begin{array}{l}-0.023 \\
(0.032)\end{array}$ & $\begin{array}{l}-0.019 \\
(0.030)\end{array}$ & $\begin{array}{c}0.015 \\
(0.036)\end{array}$ & $\begin{array}{c}0.014 \\
(0.035)\end{array}$ & $\begin{array}{c}0.008 \\
(0.034)\end{array}$ & $\begin{array}{l}0.005 \\
(0.035)\end{array}$ \\
\hline 4 & $\begin{array}{l}-0.019 \\
(0.040)\end{array}$ & $\begin{array}{l}-0.021 \\
(0.040)\end{array}$ & $\begin{array}{l}-0.022 \\
(0.041)\end{array}$ & $\begin{array}{l}-0.030 \\
(0.042)\end{array}$ & $\begin{array}{l}-0.018 \\
(0.040)\end{array}$ & $\begin{array}{c}0.026 \\
(0.043)\end{array}$ & $\begin{array}{c}0.024 \\
(0.041)\end{array}$ & $\begin{array}{c}0.018 \\
(0.040)\end{array}$ & $\begin{array}{c}0.013 \\
(0.041)\end{array}$ \\
\hline 5 & $\begin{array}{l}-0.016 \\
(0.050)\end{array}$ & $\begin{array}{l}-0.018 \\
(0.050)\end{array}$ & $\begin{array}{l}-0.018 \\
(0.050)\end{array}$ & $\begin{array}{l}-0.027 \\
(0.051)\end{array}$ & $\begin{array}{l}-0.015 \\
(0.050)\end{array}$ & $\begin{array}{c}0.027 \\
(0.048)\end{array}$ & $\begin{array}{c}0.026 \\
(0.046)\end{array}$ & $\begin{array}{c}0.019 \\
(0.045)\end{array}$ & $\begin{array}{l}0.013 \\
(0.045)\end{array}$ \\
\hline 6 & $\begin{array}{l}-0.024 \\
(0.057)\end{array}$ & $\begin{array}{l}-0.028 \\
(0.057)\end{array}$ & $\begin{array}{l}-0.028 \\
(0.057)\end{array}$ & $\begin{array}{l}-0.033 \\
(0.060)\end{array}$ & $\begin{array}{l}-0.025 \\
(0.057)\end{array}$ & $\begin{array}{c}0.032 \\
(0.053)\end{array}$ & $\begin{array}{c}0.029 \\
(0.050)\end{array}$ & $\begin{array}{c}0.021 \\
(0.049)\end{array}$ & $\begin{array}{c}0.013 \\
(0.049)\end{array}$ \\
\hline 7 & $\begin{array}{l}-0.021 \\
(0.079)\end{array}$ & $\begin{array}{l}-0.023 \\
(0.080)\end{array}$ & $\begin{array}{l}-0.020 \\
(0.080)\end{array}$ & $\begin{array}{l}-0.036 \\
(0.089) \\
\end{array}$ & $\begin{array}{l}-0.020 \\
(0.080)\end{array}$ & $\begin{array}{c}0.042 \\
(0.062) \\
\end{array}$ & $\begin{array}{c}0.041 \\
(0.059)\end{array}$ & $\begin{array}{c}0.036 \\
(0.058) \\
\end{array}$ & $\begin{array}{r}0.023 \\
(0.057) \\
\end{array}$ \\
\hline $\mathrm{N}$ & 3250 & 3250 & 3120 & 2665 & 3185 & 2600 & 2600 & 2470 & 2145 \\
\hline $\begin{array}{l}\text { Daily new cases \& } \\
\text { deaths per capita }\end{array}$ & $\mathrm{N}$ & Y & $\mathrm{Y}$ & Y & Y & $\mathrm{N}$ & Y & Y & $\mathrm{Y}$ \\
\hline Drop NY & $\mathrm{N}$ & $\mathrm{N}$ & $\mathrm{Y}$ & Y & $\mathrm{N}$ & $\mathrm{N}$ & $\mathrm{N}$ & $\mathrm{Y}$ & $\mathrm{Y}$ \\
\hline Drop NY, CA, WA & $\mathrm{N}$ & $\mathrm{N}$ & $\mathrm{N}$ & $\mathrm{Y}$ & $\mathrm{N}$ & $\mathrm{N}$ & $\mathrm{N}$ & $\mathrm{N}$ & $\mathrm{Y}$ \\
\hline Drop KS and OK & $\mathrm{N}$ & $\mathrm{N}$ & $\mathrm{N}$ & $\mathrm{N}$ & $\mathrm{Y}$ & $\mathrm{N}$ & $\mathrm{N}$ & $\mathrm{N}$ & $\mathrm{N}$ \\
\hline
\end{tabular}

Notes: The day prior the announcement of the policy is the excluded category. All models include city, state, and calendar date fixed effects. Standard errors are clustered at the state level and reported in parentheses 
Table A5. Event study estimates: Closure of non-essential businesses

\begin{tabular}{|c|c|c|c|c|c|c|c|c|c|}
\hline \multirow[b]{2}{*}{$\begin{array}{c}\text { No. of days to } \\
\text { policy }\end{array}$} & \multicolumn{5}{|c|}{ Percentage change in new listings } & \multicolumn{4}{|c|}{ Percentage change in pending sales } \\
\hline & (1) & (2) & (3) & (4) & (5) & (1) & (2) & (3) & (4) \\
\hline-7 & $\begin{array}{c}0.023 \\
(0.043)\end{array}$ & $\begin{array}{c}0.022 \\
(0.040)\end{array}$ & $\begin{array}{c}0.019 \\
(0.041)\end{array}$ & $\begin{array}{l}-0.007 \\
(0.049)\end{array}$ & $\begin{array}{c}0.044 \\
(0.039)\end{array}$ & $\begin{array}{c}0.061 \\
(0.051)\end{array}$ & $\begin{array}{c}0.060 \\
(0.046)\end{array}$ & $\begin{array}{c}0.058 \\
(0.049)\end{array}$ & $\begin{array}{c}0.000 \\
(0.038)\end{array}$ \\
\hline-6 & $\begin{array}{c}0.004 \\
(0.029)\end{array}$ & $\begin{array}{c}0.002 \\
(0.029)\end{array}$ & $\begin{array}{l}-0.002 \\
(0.030)\end{array}$ & $\begin{array}{l}-0.018 \\
(0.038)\end{array}$ & $\begin{array}{c}0.015 \\
(0.030)\end{array}$ & $\begin{array}{c}0.031 \\
(0.029)\end{array}$ & $\begin{array}{c}0.028 \\
(0.027)\end{array}$ & $\begin{array}{c}0.028 \\
(0.029)\end{array}$ & $\begin{array}{l}-0.003 \\
(0.031)\end{array}$ \\
\hline-5 & $\begin{array}{c}0.005 \\
(0.024)\end{array}$ & $\begin{array}{c}0.002 \\
(0.023)\end{array}$ & $\begin{array}{l}-0.000 \\
(0.025)\end{array}$ & $\begin{array}{l}-0.011 \\
(0.032)\end{array}$ & $\begin{array}{c}0.012 \\
(0.026)\end{array}$ & $\begin{array}{c}0.021 \\
(0.021)\end{array}$ & $\begin{array}{c}0.018 \\
(0.021)\end{array}$ & $\begin{array}{c}0.019 \\
(0.021)\end{array}$ & $\begin{array}{l}-0.005 \\
(0.026)\end{array}$ \\
\hline-4 & $\begin{array}{c}0.005 \\
(0.019)\end{array}$ & $\begin{array}{c}0.004 \\
(0.019)\end{array}$ & $\begin{array}{l}-0.001 \\
(0.020)\end{array}$ & $\begin{array}{l}-0.007 \\
(0.026)\end{array}$ & $\begin{array}{c}0.010 \\
(0.021)\end{array}$ & $\begin{array}{c}0.019 \\
(0.016)\end{array}$ & $\begin{array}{c}0.017 \\
(0.016)\end{array}$ & $\begin{array}{c}0.019 \\
(0.016)\end{array}$ & $\begin{array}{c}0.003 \\
(0.021)\end{array}$ \\
\hline-3 & $\begin{array}{c}0.004 \\
(0.013)\end{array}$ & $\begin{array}{c}0.004 \\
(0.012)\end{array}$ & $\begin{array}{c}0.001 \\
(0.013)\end{array}$ & $\begin{array}{l}-0.004 \\
(0.018)\end{array}$ & $\begin{array}{c}0.008 \\
(0.014)\end{array}$ & $\begin{array}{c}0.020 \\
(0.012)\end{array}$ & $\begin{array}{c}0.019 \\
(0.011)\end{array}$ & $\begin{array}{c}0.019 \\
(0.012)\end{array}$ & $\begin{array}{c}0.007 \\
(0.014)\end{array}$ \\
\hline-2 & $\begin{array}{c}0.003 \\
(0.007)\end{array}$ & $\begin{array}{c}0.002 \\
(0.007)\end{array}$ & $\begin{array}{l}-0.000 \\
(0.007)\end{array}$ & $\begin{array}{l}-0.003 \\
(0.009)\end{array}$ & $\begin{array}{c}0.003 \\
(0.008)\end{array}$ & $\begin{array}{c}0.010 \\
(0.007)\end{array}$ & $\begin{array}{c}0.007 \\
(0.008)\end{array}$ & $\begin{array}{c}0.010 \\
(0.007)\end{array}$ & $\begin{array}{c}0.003 \\
(0.008)\end{array}$ \\
\hline 0 & $\begin{array}{l}-0.011 \\
(0.010)\end{array}$ & $\begin{array}{l}-0.013 \\
(0.010)\end{array}$ & $\begin{array}{l}-0.016 \\
(0.011)\end{array}$ & $\begin{array}{l}-0.012 \\
(0.013)\end{array}$ & $\begin{array}{l}-0.017 \\
(0.010)\end{array}$ & $\begin{array}{c}-0.017 * * \\
(0.006)\end{array}$ & $\begin{array}{c}-0.021 * * * \\
(0.006)\end{array}$ & $\begin{array}{c}-0.024^{* * *} \\
(0.006)\end{array}$ & $\begin{array}{c}-0.024 * * \\
(0.011)\end{array}$ \\
\hline 1 & $\begin{array}{c}-0.038^{* *} \\
(0.017)\end{array}$ & $\begin{array}{c}-0.037 * \\
(0.018)\end{array}$ & $\begin{array}{c}-0.041 * * \\
(0.018)\end{array}$ & $\begin{array}{l}-0.035 \\
(0.024)\end{array}$ & $\begin{array}{c}-0.044 * * \\
(0.019)\end{array}$ & $\begin{array}{c}-0.030^{* *} \\
(0.012)\end{array}$ & $\begin{array}{c}-0.028^{* *} \\
(0.013)\end{array}$ & $\begin{array}{c}-0.034 * * \\
(0.012)\end{array}$ & $\begin{array}{l}-0.029 \\
(0.018)\end{array}$ \\
\hline 2 & $\begin{array}{c}-0.060 * * * \\
(0.020)\end{array}$ & $\begin{array}{c}-0.061 * * * \\
(0.021)\end{array}$ & $\begin{array}{c}-0.064 * * * \\
(0.021)\end{array}$ & $\begin{array}{l}-0.062^{*} \\
(0.031)\end{array}$ & $\begin{array}{c}-0.072 * * * \\
(0.022)\end{array}$ & $\begin{array}{c}-0.044^{* *} \\
(0.017)\end{array}$ & $\begin{array}{c}-0.045^{* *} \\
(0.016)\end{array}$ & $\begin{array}{c}-0.051 * * * \\
(0.015)\end{array}$ & $\begin{array}{c}-0.047^{* *} \\
(0.022)\end{array}$ \\
\hline 3 & $\begin{array}{c}-0.085^{* * *} \\
(0.024)\end{array}$ & $\begin{array}{c}-0.083 * * * \\
(0.025)\end{array}$ & $\begin{array}{c}-0.082 * * * \\
(0.025)\end{array}$ & $\begin{array}{c}-0.084 * * \\
(0.039)\end{array}$ & $\begin{array}{c}-0.097 * * * \\
(0.026)\end{array}$ & $\begin{array}{c}-0.068^{* * *} \\
(0.020)\end{array}$ & $\begin{array}{c}-0.067 * * * \\
(0.020)\end{array}$ & $\begin{array}{c}-0.076^{* * *} \\
(0.017)\end{array}$ & $\begin{array}{c}-0.069 * * \\
(0.026)\end{array}$ \\
\hline 4 & $\begin{array}{c}-0.104 * * * \\
(0.031)\end{array}$ & $\begin{array}{c}-0.102 * * * \\
(0.032)\end{array}$ & $\begin{array}{c}-0.096 * * * \\
(0.031)\end{array}$ & $\begin{array}{c}-0.106^{* *} \\
(0.046)\end{array}$ & $\begin{array}{c}-0.118^{* * *} \\
(0.035)\end{array}$ & $\begin{array}{c}-0.092^{* * *} \\
(0.021)\end{array}$ & $\begin{array}{c}-0.091 * * * \\
(0.021)\end{array}$ & $\begin{array}{c}-0.097 * * * \\
(0.021)\end{array}$ & $\begin{array}{c}-0.093^{* *} \\
(0.036)\end{array}$ \\
\hline 5 & $\begin{array}{c}-0.124 * * * \\
(0.038)\end{array}$ & $\begin{array}{c}-0.122^{* * *} \\
(0.038)\end{array}$ & $\begin{array}{c}-0.112^{* * *} \\
(0.037)\end{array}$ & $\begin{array}{c}-0.131 * * \\
(0.054)\end{array}$ & $\begin{array}{c}-0.141 * * * \\
(0.042)\end{array}$ & $\begin{array}{c}-0.115^{* * *} \\
(0.026)\end{array}$ & $\begin{array}{c}-0.113^{* * *} \\
(0.025)\end{array}$ & $\begin{array}{c}-0.120 * * * \\
(0.027)\end{array}$ & $\begin{array}{c}-0.121^{* *} \\
(0.045)\end{array}$ \\
\hline 6 & $\begin{array}{c}-0.151^{* * *} \\
(0.042)\end{array}$ & $\begin{array}{c}-0.147 * * * \\
(0.042)\end{array}$ & $\begin{array}{c}-0.140^{* * *} \\
(0.040)\end{array}$ & $\begin{array}{c}-0.158^{* *} \\
(0.058)\end{array}$ & $\begin{array}{c}-0.170^{* * *} \\
(0.045)\end{array}$ & $\begin{array}{c}-0.138^{* * *} \\
(0.030)\end{array}$ & $\begin{array}{c}-0.134^{* * *} \\
(0.030)\end{array}$ & $\begin{array}{c}-0.138^{* * *} \\
(0.032)\end{array}$ & $\begin{array}{c}-0.142^{* *} \\
(0.056)\end{array}$ \\
\hline 7 & $\begin{array}{c}-0.210^{* * *} \\
(0.050)\end{array}$ & $\begin{array}{c}-0.201 * * * \\
(0.049) \\
\end{array}$ & $\begin{array}{c}-0.189 * * * \\
(0.046) \\
\end{array}$ & $\begin{array}{c}-0.199 * * \\
(0.074) \\
\end{array}$ & $\begin{array}{c}-0.229 * * * \\
(0.049) \\
\end{array}$ & $\begin{array}{c}-0.242^{* * *} \\
(0.053)\end{array}$ & $\begin{array}{c}-0.232^{* * *} \\
(0.053) \\
\end{array}$ & $\begin{array}{c}-0.234 * * * \\
(0.055) \\
\end{array}$ & $\begin{array}{r}-0.244 * * \\
(0.096) \\
\end{array}$ \\
\hline $\mathrm{N}$ & 2210 & 2210 & 2080 & 1625 & 2145 & 1755 & 1755 & 1625 & 1300 \\
\hline $\begin{array}{l}\text { Daily new cases \& } \\
\text { deaths per capita }\end{array}$ & $\mathrm{N}$ & Y & Y & Y & Y & $\mathrm{N}$ & Y & Y & Y \\
\hline Drop NY & $\mathrm{N}$ & $\mathrm{N}$ & $\mathrm{Y}$ & Y & $\mathrm{N}$ & $\mathrm{N}$ & $\mathrm{N}$ & $\mathrm{Y}$ & $\mathrm{Y}$ \\
\hline Drop NY, CA, WA & $\mathrm{N}$ & $\mathrm{N}$ & $\mathrm{N}$ & $\mathrm{Y}$ & $\mathrm{N}$ & $\mathrm{N}$ & $\mathrm{N}$ & $\mathrm{N}$ & $\mathrm{Y}$ \\
\hline Drop KS and OK & $\mathrm{N}$ & $\mathrm{N}$ & $\mathrm{N}$ & $\mathrm{N}$ & $\mathrm{Y}$ & $\mathrm{N}$ & $\mathrm{N}$ & $\mathrm{N}$ & $\mathrm{N}$ \\
\hline
\end{tabular}

Notes: The day prior the announcement of the policy is the excluded category. All models include city, state, and calendar date fixed effects. States that did not implement the policy (AZ, FL, GA, MN, MO, OR, RI, TX, UT) are excluded from the sample Standard errors are clustered at the state level and reported in parentheses. The signs ${ }^{* *}$ and ${ }^{* * *}$ indicate statistical significance at 5 and 1 percent levels. 
Table A6. Event study estimates: Any business closures

\begin{tabular}{|c|c|c|c|c|c|c|c|c|c|}
\hline \multirow[b]{2}{*}{$\begin{array}{l}\text { No. of days to } \\
\text { policy }\end{array}$} & \multicolumn{5}{|c|}{ Percentage change in new listings } & \multicolumn{4}{|c|}{ Percentage change in pending sales } \\
\hline & (1) & $(2)$ & (3) & (4) & (5) & (1) & $(2)$ & (3) & (4) \\
\hline \multirow[t]{2}{*}{-7} & $-0.067 * *$ & $-0.055^{* *}$ & $-0.046^{*}$ & $-0.054^{*}$ & -0.042 & 0.010 & 0.027 & 0.034 & 0.036 \\
\hline & $(0.028)$ & $(0.026)$ & $(0.026)$ & $(0.028)$ & $(0.029)$ & $(0.074)$ & $(0.072)$ & $(0.072)$ & $(0.083)$ \\
\hline \multirow[t]{2}{*}{-6} & $-0.043^{* *}$ & $-0.036^{*}$ & -0.031 & -0.034 & -0.027 & 0.019 & 0.030 & 0.031 & 0.038 \\
\hline & $(0.020)$ & $(0.019)$ & $(0.019)$ & $(0.022)$ & $(0.021)$ & $(0.062)$ & $(0.061)$ & $(0.062)$ & $(0.072)$ \\
\hline \multirow[t]{2}{*}{-5} & $-0.030^{*}$ & -0.025 & -0.022 & -0.022 & -0.018 & 0.015 & 0.024 & 0.025 & 0.033 \\
\hline & $(0.016)$ & $(0.016)$ & $(0.016)$ & $(0.018)$ & $(0.018)$ & $(0.053)$ & $(0.052)$ & $(0.052)$ & $(0.061)$ \\
\hline \multirow[t]{2}{*}{-4} & -0.021 & -0.017 & -0.016 & -0.014 & -0.013 & 0.017 & 0.023 & 0.023 & 0.030 \\
\hline & $(0.013)$ & $(0.013)$ & $(0.013)$ & $(0.015)$ & $(0.015)$ & $(0.041)$ & $(0.041)$ & $(0.041)$ & $(0.049)$ \\
\hline \multirow[t]{2}{*}{-3} & -0.012 & -0.009 & -0.008 & -0.006 & -0.007 & 0.011 & 0.017 & 0.017 & 0.019 \\
\hline & $(0.010)$ & $(0.010)$ & $(0.010)$ & $(0.011)$ & $(0.011)$ & $(0.029)$ & $(0.029)$ & $(0.028)$ & $(0.035)$ \\
\hline \multirow[t]{2}{*}{-2} & -0.001 & 0.001 & -0.000 & -0.000 & 0.002 & 0.010 & 0.012 & 0.012 & 0.014 \\
\hline & $(0.005)$ & $(0.005)$ & $(0.006)$ & $(0.006)$ & $(0.006)$ & $(0.016)$ & $(0.016)$ & $(0.016)$ & $(0.020)$ \\
\hline \multirow[t]{2}{*}{0} & 0.000 & -0.001 & -0.002 & 0.002 & -0.003 & -0.002 & -0.004 & -0.002 & -0.003 \\
\hline & $(0.005)$ & $(0.005)$ & $(0.006)$ & $(0.007)$ & $(0.005)$ & $(0.012)$ & $(0.012)$ & $(0.012)$ & $(0.015)$ \\
\hline \multirow[t]{2}{*}{1} & 0.003 & 0.000 & -0.001 & 0.007 & -0.003 & -0.000 & -0.004 & -0.001 & -0.003 \\
\hline & $(0.009)$ & $(0.009)$ & $(0.010)$ & $(0.011)$ & $(0.009)$ & $(0.019)$ & $(0.019)$ & $(0.018)$ & $(0.022)$ \\
\hline \multirow[t]{2}{*}{2} & 0.012 & 0.008 & 0.006 & 0.013 & 0.004 & 0.003 & -0.002 & 0.002 & -0.002 \\
\hline & $(0.011)$ & $(0.011)$ & $(0.011)$ & $(0.013)$ & $(0.012)$ & $(0.024)$ & $(0.024)$ & $(0.023)$ & $(0.026)$ \\
\hline \multirow[t]{2}{*}{3} & 0.018 & 0.016 & 0.014 & 0.017 & 0.010 & 0.011 & 0.006 & 0.009 & 0.006 \\
\hline & $(0.013)$ & $(0.014)$ & $(0.015)$ & $(0.016)$ & $(0.016)$ & $(0.026)$ & $(0.025)$ & $(0.024)$ & $(0.027)$ \\
\hline \multirow[t]{2}{*}{4} & 0.028 & 0.023 & 0.022 & 0.019 & 0.018 & 0.022 & 0.013 & 0.018 & 0.014 \\
\hline & $(0.017)$ & $(0.017)$ & $(0.018)$ & $(0.018)$ & $(0.022)$ & $(0.028)$ & $(0.026)$ & $(0.026)$ & $(0.027)$ \\
\hline \multirow[t]{2}{*}{5} & 0.032 & 0.027 & 0.025 & 0.020 & 0.021 & 0.027 & 0.017 & 0.019 & 0.010 \\
\hline & $(0.020)$ & $(0.020)$ & $(0.021)$ & $(0.022)$ & $(0.026)$ & $(0.032)$ & $(0.030)$ & $(0.030)$ & $(0.030)$ \\
\hline \multirow[t]{2}{*}{6} & $0.039 *$ & 0.035 & 0.031 & 0.032 & 0.028 & 0.031 & 0.022 & 0.023 & 0.013 \\
\hline & $(0.023)$ & $(0.024)$ & $(0.025)$ & $(0.028)$ & $(0.030)$ & $(0.033)$ & $(0.031)$ & $(0.030)$ & $(0.030)$ \\
\hline \multirow[t]{2}{*}{7} & 0.047 & 0.044 & 0.046 & 0.040 & 0.039 & 0.037 & 0.027 & 0.024 & 0.008 \\
\hline & $(0.030)$ & $(0.031)$ & $(0.034)$ & $(0.037)$ & $(0.039)$ & $(0.041)$ & $(0.039)$ & $(0.039)$ & $(0.038)$ \\
\hline $\mathrm{N}$ & 3185 & 3185 & 3055 & 2600 & 3120 & 2535 & 2535 & 2405 & 2080 \\
\hline \multicolumn{10}{|l|}{ Daily new cases \& } \\
\hline deaths per capita & $\mathrm{N}$ & $\mathrm{Y}$ & $\mathrm{Y}$ & $\mathrm{Y}$ & $\mathrm{Y}$ & $\mathrm{N}$ & $\mathrm{Y}$ & $\mathrm{Y}$ & $\mathrm{Y}$ \\
\hline Drop NY & $\mathrm{N}$ & $\mathrm{N}$ & $\mathrm{Y}$ & $\mathrm{Y}$ & $\mathrm{N}$ & $\mathrm{N}$ & $\mathrm{N}$ & $\mathrm{Y}$ & Y \\
\hline Drop NY, CA, WA & $\mathrm{N}$ & $\mathrm{N}$ & $\mathrm{N}$ & $\mathrm{Y}$ & $\mathrm{N}$ & $\mathrm{N}$ & $\mathrm{N}$ & $\mathrm{N}$ & $\mathrm{Y}$ \\
\hline Drop KS and OK & $\mathrm{N}$ & $\mathrm{N}$ & $\mathrm{N}$ & $\mathrm{N}$ & $\mathrm{Y}$ & $\mathrm{N}$ & $\mathrm{N}$ & $\mathrm{N}$ & $\mathrm{N}$ \\
\hline
\end{tabular}

Notes: The day prior the announcement of the policy is the excluded category. All models include city, state, and calendar date fixed effects. States that did not implement the policy (AZ) are excluded from the sample Standard errors are clustered at the state level and reported in parentheses. The signs * and ** indicate statistical significance at 10 and 5 percent levels. 
Table A7. Event study estimates: Stay at home orders

\begin{tabular}{|c|c|c|c|c|c|c|c|c|c|}
\hline \multirow[b]{2}{*}{$\begin{array}{l}\text { No. of days to } \\
\text { policy }\end{array}$} & \multicolumn{5}{|c|}{ Percentage change in new listings } & \multicolumn{4}{|c|}{ Percentage change in pending sales } \\
\hline & (1) & (2) & (3) & (4) & (5) & (1) & (2) & (3) & (4) \\
\hline-7 & $\begin{array}{l}-0.021 \\
(0.039)\end{array}$ & $\begin{array}{l}-0.024 \\
(0.038)\end{array}$ & $\begin{array}{l}-0.030 \\
(0.043)\end{array}$ & $\begin{array}{l}-0.086 \\
(0.052)\end{array}$ & $\begin{array}{l}-0.024 \\
(0.038)\end{array}$ & $\begin{array}{c}0.004 \\
(0.038)\end{array}$ & $\begin{array}{c}0.002 \\
(0.039)\end{array}$ & $\begin{array}{c}0.001 \\
(0.043)\end{array}$ & $\begin{array}{l}-0.048 \\
(0.039)\end{array}$ \\
\hline-6 & $\begin{array}{l}-0.033 \\
(0.028)\end{array}$ & $\begin{array}{l}-0.036 \\
(0.028)\end{array}$ & $\begin{array}{l}-0.044 \\
(0.032)\end{array}$ & $\begin{array}{l}-0.076^{*} \\
(0.040)\end{array}$ & $\begin{array}{l}-0.036 \\
(0.028)\end{array}$ & $\begin{array}{c}0.001 \\
(0.021)\end{array}$ & $\begin{array}{l}-0.003 \\
(0.023)\end{array}$ & $\begin{array}{l}-0.002 \\
(0.025)\end{array}$ & $\begin{array}{l}-0.021 \\
(0.031)\end{array}$ \\
\hline-5 & $\begin{array}{l}-0.026 \\
(0.023)\end{array}$ & $\begin{array}{l}-0.028 \\
(0.023)\end{array}$ & $\begin{array}{l}-0.034 \\
(0.026)\end{array}$ & $\begin{array}{l}-0.058 \\
(0.034)\end{array}$ & $\begin{array}{l}-0.028 \\
(0.023)\end{array}$ & $\begin{array}{c}0.001 \\
(0.017)\end{array}$ & $\begin{array}{l}-0.002 \\
(0.019)\end{array}$ & $\begin{array}{c}0.001 \\
(0.021)\end{array}$ & $\begin{array}{l}-0.013 \\
(0.026)\end{array}$ \\
\hline-4 & $\begin{array}{l}-0.017 \\
(0.018)\end{array}$ & $\begin{array}{l}-0.018 \\
(0.018)\end{array}$ & $\begin{array}{l}-0.024 \\
(0.020)\end{array}$ & $\begin{array}{l}-0.038 \\
(0.027)\end{array}$ & $\begin{array}{l}-0.018 \\
(0.018)\end{array}$ & $\begin{array}{c}0.001 \\
(0.013)\end{array}$ & $\begin{array}{l}-0.000 \\
(0.015)\end{array}$ & $\begin{array}{c}0.002 \\
(0.016)\end{array}$ & $\begin{array}{l}-0.008 \\
(0.020)\end{array}$ \\
\hline-3 & $\begin{array}{l}-0.013 \\
(0.013)\end{array}$ & $\begin{array}{l}-0.014 \\
(0.013)\end{array}$ & $\begin{array}{l}-0.018 \\
(0.014)\end{array}$ & $\begin{array}{l}-0.027 \\
(0.019)\end{array}$ & $\begin{array}{l}-0.014 \\
(0.013)\end{array}$ & $\begin{array}{c}0.006 \\
(0.010)\end{array}$ & $\begin{array}{l}0.005 \\
(0.011)\end{array}$ & $\begin{array}{c}0.006 \\
(0.012)\end{array}$ & $\begin{array}{l}-0.003 \\
(0.014)\end{array}$ \\
\hline-2 & $\begin{array}{l}-0.001 \\
(0.007)\end{array}$ & $\begin{array}{l}-0.004 \\
(0.008)\end{array}$ & $\begin{array}{l}-0.005 \\
(0.008)\end{array}$ & $\begin{array}{l}-0.009 \\
(0.010)\end{array}$ & $\begin{array}{l}-0.004 \\
(0.008)\end{array}$ & $\begin{array}{c}0.002 \\
(0.006)\end{array}$ & $\begin{array}{l}-0.001 \\
(0.008)\end{array}$ & $\begin{array}{c}0.001 \\
(0.008)\end{array}$ & $\begin{array}{l}-0.004 \\
(0.009)\end{array}$ \\
\hline 0 & $\begin{array}{l}-0.011 \\
(0.009)\end{array}$ & $\begin{array}{l}-0.012 \\
(0.009)\end{array}$ & $\begin{array}{l}-0.013 \\
(0.010)\end{array}$ & $\begin{array}{l}-0.009 \\
(0.011)\end{array}$ & $\begin{array}{l}-0.012 \\
(0.009)\end{array}$ & $\begin{array}{l}-0.003 \\
(0.006)\end{array}$ & $\begin{array}{l}-0.003 \\
(0.006)\end{array}$ & $\begin{array}{l}-0.005 \\
(0.006)\end{array}$ & $\begin{array}{l}-0.003 \\
(0.007)\end{array}$ \\
\hline 1 & $\begin{array}{l}-0.024 \\
(0.016)\end{array}$ & $\begin{array}{l}-0.023 \\
(0.017)\end{array}$ & $\begin{array}{l}-0.023 \\
(0.018)\end{array}$ & $\begin{array}{l}-0.015 \\
(0.020)\end{array}$ & $\begin{array}{l}-0.023 \\
(0.017)\end{array}$ & $\begin{array}{c}0.001 \\
(0.011)\end{array}$ & $\begin{array}{c}0.001 \\
(0.011)\end{array}$ & $\begin{array}{l}-0.002 \\
(0.011)\end{array}$ & $\begin{array}{c}0.005 \\
(0.013)\end{array}$ \\
\hline 2 & $\begin{array}{l}-0.026 \\
(0.021)\end{array}$ & $\begin{array}{l}-0.027 \\
(0.021)\end{array}$ & $\begin{array}{l}-0.023 \\
(0.023)\end{array}$ & $\begin{array}{l}-0.014 \\
(0.026)\end{array}$ & $\begin{array}{l}-0.027 \\
(0.021)\end{array}$ & $\begin{array}{c}0.002 \\
(0.015)\end{array}$ & $\begin{array}{c}0.001 \\
(0.014)\end{array}$ & $\begin{array}{l}-0.002 \\
(0.015)\end{array}$ & $\begin{array}{c}0.009 \\
(0.018)\end{array}$ \\
\hline 3 & $\begin{array}{l}-0.039 \\
(0.024)\end{array}$ & $\begin{array}{l}-0.036 \\
(0.025)\end{array}$ & $\begin{array}{l}-0.029 \\
(0.027)\end{array}$ & $\begin{array}{l}-0.019 \\
(0.033)\end{array}$ & $\begin{array}{l}-0.036 \\
(0.025)\end{array}$ & $\begin{array}{l}-0.001 \\
(0.019)\end{array}$ & $\begin{array}{c}0.003 \\
(0.020)\end{array}$ & $\begin{array}{l}-0.000 \\
(0.020)\end{array}$ & $\begin{array}{l}0.015 \\
(0.024)\end{array}$ \\
\hline 4 & $\begin{array}{l}-0.050^{*} \\
(0.027)\end{array}$ & $\begin{array}{l}-0.046 \\
(0.028)\end{array}$ & $\begin{array}{l}-0.037 \\
(0.029)\end{array}$ & $\begin{array}{l}-0.030 \\
(0.040)\end{array}$ & $\begin{array}{l}-0.046 \\
(0.028)\end{array}$ & $\begin{array}{l}-0.008 \\
(0.021)\end{array}$ & $\begin{array}{l}-0.004 \\
(0.021)\end{array}$ & $\begin{array}{l}-0.007 \\
(0.022)\end{array}$ & $\begin{array}{l}0.011 \\
(0.029)\end{array}$ \\
\hline 5 & $\begin{array}{c}-0.063^{* *} \\
(0.030)\end{array}$ & $\begin{array}{l}-0.060^{*} \\
(0.030)\end{array}$ & $\begin{array}{l}-0.047 \\
(0.030)\end{array}$ & $\begin{array}{l}-0.039 \\
(0.043)\end{array}$ & $\begin{array}{l}-0.060^{*} \\
(0.030)\end{array}$ & $\begin{array}{l}-0.012 \\
(0.023)\end{array}$ & $\begin{array}{l}-0.009 \\
(0.023)\end{array}$ & $\begin{array}{l}-0.011 \\
(0.024)\end{array}$ & $\begin{array}{l}0.009 \\
(0.032)\end{array}$ \\
\hline 6 & $\begin{array}{c}-0.075^{* *} \\
(0.032)\end{array}$ & $\begin{array}{c}-0.071^{* *} \\
(0.033)\end{array}$ & $\begin{array}{l}-0.05)^{*} \\
(0.034)\end{array}$ & $\begin{array}{l}-0.044 \\
(0.047)\end{array}$ & $\begin{array}{c}-0.071 * * \\
(0.033)\end{array}$ & $\begin{array}{l}-0.014 \\
(0.025)\end{array}$ & $\begin{array}{l}-0.009 \\
(0.026)\end{array}$ & $\begin{array}{l}-0.010 \\
(0.028)\end{array}$ & $\begin{array}{l}0.014 \\
(0.038)\end{array}$ \\
\hline 7 & $\begin{array}{c}-0.118^{* *} \\
(0.047)\end{array}$ & $\begin{array}{c}-0.104^{* *} \\
(0.045)\end{array}$ & $\begin{array}{l}-0.082^{*} \\
(0.046)\end{array}$ & $\begin{array}{l}-0.058 \\
(0.059)\end{array}$ & $\begin{array}{c}-0.104^{* *} \\
(0.045)\end{array}$ & $\begin{array}{l}-0.061 \\
(0.047)\end{array}$ & $\begin{array}{l}-0.046 \\
(0.049)\end{array}$ & $\begin{array}{l}-0.038 \\
(0.052)\end{array}$ & $\begin{array}{l}0.006 \\
(0.063)\end{array}$ \\
\hline $\mathrm{N}$ & 2925 & 2925 & 2795 & 2340 & 2925 & 2340 & 2340 & 2210 & 1885 \\
\hline $\begin{array}{l}\text { Daily new cases \& } \\
\text { deaths per capita }\end{array}$ & $\mathrm{N}$ & $\mathrm{Y}$ & Y & Y & Y & $\mathrm{N}$ & Y & $\mathrm{Y}$ & $\mathrm{Y}$ \\
\hline Drop NY & $\mathrm{N}$ & $\mathrm{N}$ & $\mathrm{Y}$ & $\mathrm{Y}$ & $\mathrm{N}$ & $\mathrm{N}$ & $\mathrm{N}$ & $\mathrm{Y}$ & $\mathrm{Y}$ \\
\hline Drop NY, CA, WA & $\mathrm{N}$ & $\mathrm{N}$ & $\mathrm{N}$ & Y & $\mathrm{N}$ & $\mathrm{N}$ & $\mathrm{N}$ & $\mathrm{N}$ & $\mathrm{Y}$ \\
\hline Drop KS and OK & $\mathrm{N}$ & $\mathrm{N}$ & $\mathrm{N}$ & $\mathrm{N}$ & $\mathrm{Y}$ & $\mathrm{N}$ & $\mathrm{N}$ & $\mathrm{N}$ & $\mathrm{N}$ \\
\hline
\end{tabular}

Notes: The day prior the announcement of the policy is the excluded category. All models include city, state, and calendar date fixed effects. States that did not implement the policy (UT, CT, KY, OK, MA) are excluded from the sample Standard errors are clustered at the state level and reported in parentheses. The signs * and ** indicate statistical significance at 10 and 5 percent levels. 
Table A8. Event study estimates: Change in web page views of for-sale homes

\begin{tabular}{|c|c|c|c|c|c|c|c|c|c|c|}
\hline \multirow[b]{2}{*}{$\begin{array}{l}\text { No. of days to } \\
\text { policy }\end{array}$} & \multicolumn{2}{|c|}{$\begin{array}{c}\text { Ban on mass } \\
\text { gatherings }\end{array}$} & \multicolumn{2}{|c|}{ School closures } & \multicolumn{2}{|c|}{$\begin{array}{c}\text { Non-essential } \\
\text { business closures }\end{array}$} & \multicolumn{2}{|c|}{$\begin{array}{c}\text { Any business } \\
\text { closures }\end{array}$} & \multicolumn{2}{|c|}{ Stay at home orders } \\
\hline & (1) & (2) & (1) & (2) & (1) & (2) & (1) & (2) & (1) & (2) \\
\hline-7 & $\begin{array}{l}-0.045 \\
(0.027)\end{array}$ & $\begin{array}{l}-0.037 \\
(0.024)\end{array}$ & $\begin{array}{c}0.028 \\
(0.046)\end{array}$ & $\begin{array}{c}0.036 \\
(0.043)\end{array}$ & $\begin{array}{c}0.007 \\
(0.018)\end{array}$ & $\begin{array}{c}0.003 \\
(0.017)\end{array}$ & $\begin{array}{l}-0.021 \\
(0.038)\end{array}$ & $\begin{array}{l}-0.012 \\
(0.034)\end{array}$ & $\begin{array}{l}-0.030 \\
(0.025)\end{array}$ & $\begin{array}{l}-0.027 \\
(0.021)\end{array}$ \\
\hline-6 & $\begin{array}{c}-0.018^{*} \\
(0.010)\end{array}$ & $\begin{array}{l}-0.015 \\
(0.010)\end{array}$ & $\begin{array}{c}0.026 \\
(0.030)\end{array}$ & $\begin{array}{c}0.031 \\
(0.028)\end{array}$ & $\begin{array}{c}0.016 \\
(0.010)\end{array}$ & $\begin{array}{c}0.012 \\
(0.009)\end{array}$ & $\begin{array}{c}0.000 \\
(0.023)\end{array}$ & $\begin{array}{c}0.005 \\
(0.021)\end{array}$ & $\begin{array}{l}-0.006 \\
(0.014)\end{array}$ & $\begin{array}{l}-0.008 \\
(0.012)\end{array}$ \\
\hline-5 & $\begin{array}{l}-0.013 \\
(0.009)\end{array}$ & $\begin{array}{l}-0.010 \\
(0.008)\end{array}$ & $\begin{array}{c}0.022 \\
(0.024)\end{array}$ & $\begin{array}{c}0.026 \\
(0.023)\end{array}$ & $\begin{array}{c}0.015 \\
(0.009)\end{array}$ & $\begin{array}{c}0.011 \\
(0.008)\end{array}$ & $\begin{array}{c}0.003 \\
(0.019)\end{array}$ & $\begin{array}{c}0.007 \\
(0.017)\end{array}$ & $\begin{array}{l}-0.005 \\
(0.011)\end{array}$ & $\begin{array}{l}-0.005 \\
(0.011)\end{array}$ \\
\hline-4 & $\begin{array}{l}-0.007 \\
(0.007)\end{array}$ & $\begin{array}{l}-0.006 \\
(0.006)\end{array}$ & $\begin{array}{c}0.019 \\
(0.019)\end{array}$ & $\begin{array}{c}0.022 \\
(0.017)\end{array}$ & $\begin{array}{l}0.013^{*} \\
(0.007)\end{array}$ & $\begin{array}{l}0.012 * \\
(0.006)\end{array}$ & $\begin{array}{c}0.005 \\
(0.014)\end{array}$ & $\begin{array}{c}0.008 \\
(0.013)\end{array}$ & $\begin{array}{l}-0.001 \\
(0.009)\end{array}$ & $\begin{array}{l}-0.001 \\
(0.008)\end{array}$ \\
\hline-3 & $\begin{array}{l}-0.004 \\
(0.004)\end{array}$ & $\begin{array}{l}-0.002 \\
(0.004)\end{array}$ & $\begin{array}{c}0.012 \\
(0.012)\end{array}$ & $\begin{array}{c}0.014 \\
(0.012)\end{array}$ & $\begin{array}{c}0.010^{* *} \\
(0.005)\end{array}$ & $\begin{array}{l}0.010^{* *} \\
(0.004)\end{array}$ & $\begin{array}{c}0.004 \\
(0.010)\end{array}$ & $\begin{array}{c}0.007 \\
(0.009)\end{array}$ & $\begin{array}{c}0.002 \\
(0.006)\end{array}$ & $\begin{array}{c}0.002 \\
(0.006)\end{array}$ \\
\hline-2 & $\begin{array}{l}-0.002 \\
(0.002)\end{array}$ & $\begin{array}{l}-0.002 \\
(0.002)\end{array}$ & $\begin{array}{c}0.005 \\
(0.006)\end{array}$ & $\begin{array}{c}0.006 \\
(0.006)\end{array}$ & $\begin{array}{c}0.007^{* * *} \\
(0.002)\end{array}$ & $\begin{array}{l}0.006^{* *} \\
(0.002)\end{array}$ & $\begin{array}{c}0.003 \\
(0.005)\end{array}$ & $\begin{array}{c}0.004 \\
(0.004)\end{array}$ & $\begin{array}{c}0.004 \\
(0.003)\end{array}$ & $\begin{array}{c}0.001 \\
(0.004)\end{array}$ \\
\hline 0 & $\begin{array}{c}0.002 \\
(0.002)\end{array}$ & $\begin{array}{c}0.001 \\
(0.002)\end{array}$ & $\begin{array}{l}-0.005 \\
(0.005)\end{array}$ & $\begin{array}{l}-0.005 \\
(0.005)\end{array}$ & $\begin{array}{c}-0.009 \text { *** } \\
(0.003)\end{array}$ & $\begin{array}{c}-0.011^{* * *} \\
(0.003)\end{array}$ & $\begin{array}{l}-0.003 \\
(0.004)\end{array}$ & $\begin{array}{l}-0.004 \\
(0.004)\end{array}$ & $\begin{array}{l}-0.005 \\
(0.003)\end{array}$ & $\begin{array}{l}-0.006 \\
(0.004)\end{array}$ \\
\hline 1 & $\begin{array}{c}0.004 \\
(0.004)\end{array}$ & $\begin{array}{c}0.003 \\
(0.003)\end{array}$ & $\begin{array}{l}-0.006 \\
(0.010)\end{array}$ & $\begin{array}{l}-0.007 \\
(0.009)\end{array}$ & $\begin{array}{c}-0.018^{* * *} \\
(0.006)\end{array}$ & $\begin{array}{c}-0.016^{* *} \\
(0.006)\end{array}$ & $\begin{array}{l}-0.005 \\
(0.008)\end{array}$ & $\begin{array}{l}-0.007 \\
(0.007)\end{array}$ & $\begin{array}{l}-0.008 \\
(0.006)\end{array}$ & $\begin{array}{l}-0.009 \\
(0.006)\end{array}$ \\
\hline 2 & $\begin{array}{c}0.007 \\
(0.005)\end{array}$ & $\begin{array}{l}0.005 \\
(0.005)\end{array}$ & $\begin{array}{l}-0.009 \\
(0.014)\end{array}$ & $\begin{array}{l}-0.012 \\
(0.012)\end{array}$ & $\begin{array}{c}-0.028^{* * *} \\
(0.009)\end{array}$ & $\begin{array}{c}-0.027^{* * *} \\
(0.009)\end{array}$ & $\begin{array}{l}-0.006 \\
(0.011)\end{array}$ & $\begin{array}{l}-0.009 \\
(0.009)\end{array}$ & $\begin{array}{l}-0.011 \\
(0.009)\end{array}$ & $\begin{array}{l}-0.013 \\
(0.009)\end{array}$ \\
\hline 3 & $\begin{array}{c}0.007 \\
(0.007)\end{array}$ & $\begin{array}{c}0.005 \\
(0.006)\end{array}$ & $\begin{array}{l}-0.010 \\
(0.017)\end{array}$ & $\begin{array}{l}-0.013 \\
(0.016)\end{array}$ & $\begin{array}{c}-0.036 \text { *** } \\
(0.013)\end{array}$ & $\begin{array}{c}-0.033^{* * *} \\
(0.012)\end{array}$ & $\begin{array}{l}-0.006 \\
(0.014)\end{array}$ & $\begin{array}{l}-0.007 \\
(0.012)\end{array}$ & $\begin{array}{l}-0.015 \\
(0.011)\end{array}$ & $\begin{array}{l}-0.013 \\
(0.010)\end{array}$ \\
\hline 4 & $\begin{array}{c}0.009 \\
(0.009)\end{array}$ & $\begin{array}{c}0.006 \\
(0.008)\end{array}$ & $\begin{array}{l}-0.006 \\
(0.021)\end{array}$ & $\begin{array}{l}-0.010 \\
(0.019)\end{array}$ & $\begin{array}{c}-0.042^{* * *} \\
(0.014)\end{array}$ & $\begin{array}{c}-0.038^{* *} \\
(0.014)\end{array}$ & $\begin{array}{l}-0.002 \\
(0.017)\end{array}$ & $\begin{array}{l}-0.005 \\
(0.014)\end{array}$ & $\begin{array}{l}-0.019 \\
(0.012)\end{array}$ & $\begin{array}{l}-0.018 \\
(0.012)\end{array}$ \\
\hline 5 & $\begin{array}{c}0.012 \\
(0.010)\end{array}$ & $\begin{array}{c}0.008 \\
(0.009)\end{array}$ & $\begin{array}{l}-0.003 \\
(0.025)\end{array}$ & $\begin{array}{l}-0.008 \\
(0.022)\end{array}$ & $\begin{array}{c}-0.049 * * * \\
(0.016)\end{array}$ & $\begin{array}{c}-0.045^{* * *} \\
(0.016)\end{array}$ & $\begin{array}{c}0.002 \\
(0.021)\end{array}$ & $\begin{array}{l}-0.001 \\
(0.018)\end{array}$ & $\begin{array}{l}-0.020 \\
(0.014)\end{array}$ & $\begin{array}{l}-0.020 \\
(0.013)\end{array}$ \\
\hline 6 & $\begin{array}{c}0.017 \\
(0.012)\end{array}$ & $\begin{array}{c}0.014 \\
(0.010)\end{array}$ & $\begin{array}{c}0.000 \\
(0.029)\end{array}$ & $\begin{array}{l}-0.007 \\
(0.026)\end{array}$ & $\begin{array}{c}-0.056 \text { *** } \\
(0.019)\end{array}$ & $\begin{array}{c}-0.051^{* * *} \\
(0.018)\end{array}$ & $\begin{array}{c}0.005 \\
(0.025)\end{array}$ & $\begin{array}{c}0.003 \\
(0.021)\end{array}$ & $\begin{array}{l}-0.018 \\
(0.015)\end{array}$ & $\begin{array}{l}-0.018 \\
(0.013)\end{array}$ \\
\hline 7 & $\begin{array}{r}0.019 \\
(0.022) \\
\end{array}$ & $\begin{array}{c}0.016 \\
(0.020) \\
\end{array}$ & $\begin{array}{c}0.012 \\
(0.036) \\
\end{array}$ & $\begin{array}{c}0.007 \\
(0.032) \\
\end{array}$ & $\begin{array}{c}-0.089^{* *} \\
(0.032) \\
\end{array}$ & $\begin{array}{c}-0.077^{* *} \\
(0.029) \\
\end{array}$ & $\begin{array}{l}-0.000 \\
(0.039) \\
\end{array}$ & $\begin{array}{c}0.001 \\
(0.033) \\
\end{array}$ & $\begin{array}{l}-0.029 \\
(0.028) \\
\end{array}$ & $\begin{array}{l}-0.023 \\
(0.024) \\
\end{array}$ \\
\hline $\begin{array}{l}\text { Daily new } \\
\text { cases \& deaths } \\
\text { per capita }\end{array}$ & $\mathrm{N}$ & Y & $\mathrm{N}$ & $\mathrm{Y}$ & $\mathrm{N}$ & Y & $\mathrm{N}$ & Y & $\mathrm{N}$ & Y \\
\hline
\end{tabular}

Notes: The day prior the announcement of the policy is the excluded category. All models include city, state, and calendar date fixed effects. Number of observations for all models is 2300 . Standard errors are clustered at the state level and reported in parentheses. The signs ${ }^{*},{ }^{* *},{ }^{* *}$ indicate statistical significance at 10,5 , and 1 percent levels. 